\title{
Inorganic geochemistry data from Lake El'gygytgyn sediments: marine isotope stages 6-11
}

\author{
P. S. Minyuk ${ }^{1}$, V. Y. Borkhodoev ${ }^{1}$, and V. Wennrich ${ }^{2}$ \\ ${ }^{1}$ North-East Interdisciplinary Scientific Research Institute of Far East Branch of Russian Academy of Science, \\ Magadan, Russia \\ ${ }^{2}$ University of Cologne, Institute for Geology and Mineralogy, Cologne, Germany \\ Correspondence to: P. S. Minyuk (minyuk@ neisri.ru)
}

Received: 14 November 2012 - Published in Clim. Past Discuss.: 21 January 2013

Revised: 5 July 2013 - Accepted: 5 February 2014 - Published: 12 March 2014

\begin{abstract}
Geochemical analyses were performed on sediments recovered by deep drilling at Lake El'gygytgyn in central Chukotka, northeastern Russia $\left(67^{\circ} 30^{\prime} \mathrm{N} ; 172^{\circ} 05^{\prime} \mathrm{E}\right)$. Major and rare element concentrations were determined using X-ray fluorescence spectroscopy (XRF) on the $<250 \mu \mathrm{m}$ fraction from 617 samples dated to ca. 440 and $125 \mathrm{ka}$, which approximates marine isotope stages (MIS) 11 to 6 . The inorganic geochemistry indicates significant variations in elemental composition between glaciations and interglaciations. Interglacial sediments are characterized by high contents of $\mathrm{SiO}_{2}, \mathrm{Na}_{2} \mathrm{O}, \mathrm{CaO}, \mathrm{K}_{2} \mathrm{O}$, and $\mathrm{Sr}$ and are depleted in $\mathrm{Al}_{2} \mathrm{O}_{3}$, $\mathrm{Fe}_{2} \mathrm{O}_{3}, \mathrm{TiO}_{2}$, and $\mathrm{MgO}$. An extreme $\mathrm{SiO}_{2}$ enrichment during MIS 11.3 and 9.3 was caused by an enhanced flux of biogenic silica (BSi). The geochemical structure of MIS 11 shows similar characteristics as seen in MIS 11 records from Lake Baikal (southeastern Siberia) and Antarctic ice cores, thereby arguing for the influence of global forcings on these records. High sediment content of $\mathrm{TiO}_{2}, \mathrm{Fe}_{2} \mathrm{O}_{3}, \mathrm{MgO}, \mathrm{Al}_{2} \mathrm{O}_{3}$, LOI, $\mathrm{Ni}, \mathrm{Cr}$, and $\mathrm{Zr}$ typifies glacial stages, with the most marked increases during MIS 7.4 and 6.6. Reducing conditions during glacial times are indicated by peaks in the $\mathrm{Fe}_{2} \mathrm{O}_{3}$ content and coinciding low $\mathrm{Fe}_{2} \mathrm{O}_{3} / \mathrm{MnO}$ ratios. This conclusion also is supported by $\mathrm{P}_{2} \mathrm{O}_{5}$ and $\mathrm{MnO}$ enrichment, indicating an increased abundance of authigenic, fine-grained vivianite. Elemental ratios (CIA, CIW, PIA, and $\mathrm{Rb} / \mathrm{Sr}$ ) indicate that glacial sediments are depleted in mobile elements, like $\mathrm{Na}, \mathrm{Ca}, \mathrm{K}$ and $\mathrm{Sr}$. This depletion was caused by changes in the sedimentation regime and thus reflects environmental changes.
\end{abstract}

\section{Introduction}

Lake El'gygytgyn $\left(67^{\circ} 30^{\prime} \mathrm{N}, 172^{\circ} 05^{\prime} \mathrm{E}\right)$ was drilled to recover $318 \mathrm{~m}$ of lacustrine sediment, providing the first continuous record of past climate change in the terrestrial Arctic spanning the last 3.6 Ma (Melles et al., 2011, 2012; BrighamGrette et al., 2013; Nowaczyk et al., 2013). Prior to the deep drilling effort in 2009, several short pilot cores were previously collected from other areas of the lake. The first inorganic geochemical data from El'gygytgyn were obtained from cores PG1351 (ca. $13 \mathrm{~m}$ length) and Lz1024 (ca. $16 \mathrm{~m}$ length) with basal ages of ca. 250 and $350 \mathrm{kyr} \mathrm{BP}$, respectively (Minyuk et al., 2007, 2011). Based on the distribution of major and rare elements, the cores were divided into geochemical zones corresponding to marine isotopic stages (MIS) 1-MIS 10. Sediments from the warm climatic stages are enriched in $\mathrm{SiO}_{2}, \mathrm{CaO}, \mathrm{Na}_{2} \mathrm{O}, \mathrm{K}_{2} \mathrm{O}$, and $\mathrm{Sr}$, but depleted in $\mathrm{TiO}_{2}, \mathrm{Al}_{2} \mathrm{O}_{3}, \mathrm{MgO}, \mathrm{Fe}_{2} \mathrm{O}_{3}$, and LOI. Glacial sediments are relatively low in mobile elements, such as $\mathrm{Ca}, \mathrm{Na}$, and $\mathrm{K}$, but show higher values of the chemical index of alteration (CIA), the plagioclase index of alteration (PIA), and the $\mathrm{Rb} / \mathrm{Sr}$ ratio (Minyuk et al., 2007, 2011). In this paper, we focus on the geochemical characterization of sediments from the upper part of ICDP core 5011-1, spanning MIS 6 to MIS 11. This interval encompasses great climatic variations from the maximum temperatures of the "super" interglacials (MIS 11 and MIS 9) to the extreme cold of MIS 6 and MIS 8 (Melles et al., 2012; Matrosova, 2009; Lozhkin et al., 2013). 

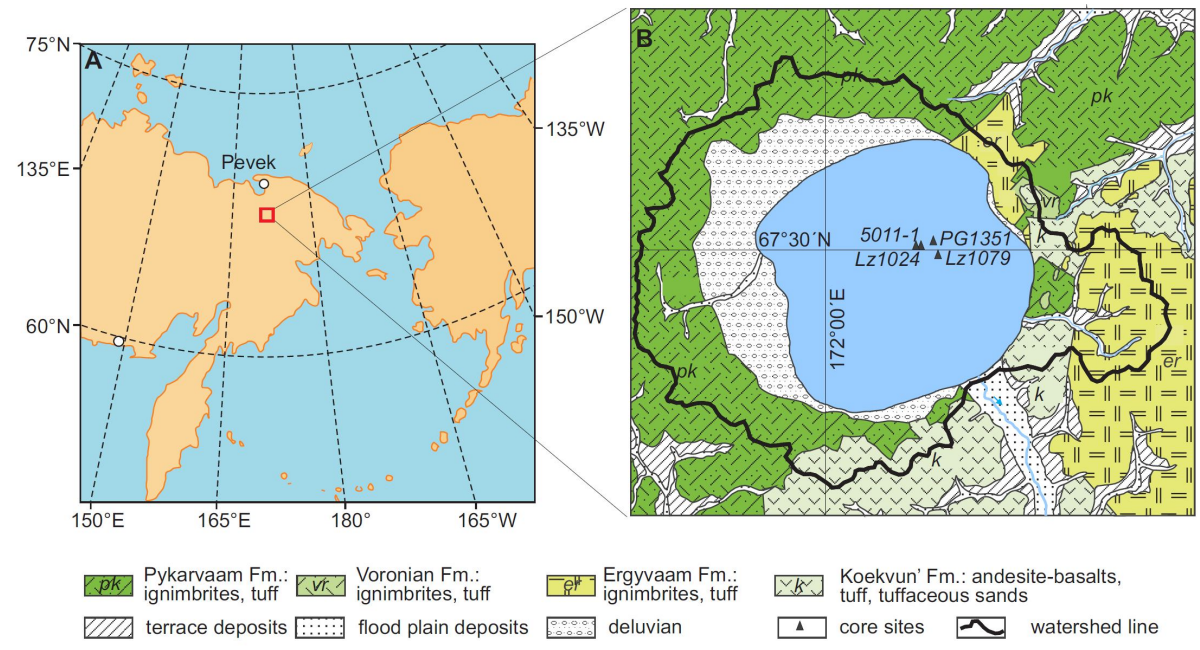

Fig. 1. Location (A) and geological map (B) of the El'gygytgyn area adapted from Bely and Raikevich (1994) and Bely and Belaya (1998).

\subsection{Location and setting}

Lake El'gygytgyn $\left(67^{\circ} 30^{\prime} \mathrm{N} ; 172^{\circ} 05^{\prime} \mathrm{E}\right)$ is located in central Chukotka, northeastern Russia. The lake, which is ca. $12 \mathrm{~km}$ across with a depth of $174 \mathrm{~m}$ depth, is situated within an $18 \mathrm{~km}$-wide meteorite crater (Fig. 1) that was created $3.58 \pm 0.04 \mathrm{Ma}$ in Upper Cretaceous volcanic rocks (Layer, 2000). Within the ca. $293 \mathrm{~km}^{2}$ catchment area, approximately 50 streams, which are mostly less than $5 \mathrm{~km}$ in length, drain into the lake (Nolan and Brigham-Grette, 2007). The only outlet is the Enmyvaam River that flows south to the Bering Sea. Lake El'gygytgyn is monomictic and oligotrophic, with summer water temperatures of $<4{ }^{\circ} \mathrm{C}$ (Cremer and Wagner, 2003; Nolan and Brigham-Grette, 2007). The lake water is characterized by low ion concentrations. Minimum and maximum values obtained in spring and summer, 2003, were measured along vertical profiles through the water column at sites Lz1024 and Lz1079. These ranges include: $\mathrm{Ca}^{2+}=0.71-1.05 \mathrm{mg} \mathrm{L}^{-1}$ (Lz1024), 0.69$0.72 \mathrm{mg} \mathrm{L}^{-1}$ (Lz1079); $\mathrm{Mg}^{2+}=0.11-0.19 \mathrm{mg} \mathrm{L}^{-1}$ (Lz1024), $0.11-0.12 \mathrm{mg} \mathrm{L}^{-1} ; \quad \mathrm{Na}^{+}=0.53-1.24 \mathrm{mg} \mathrm{L}^{-1} \quad$ (Lz1024), $0.49-0.57 \mathrm{mg} \mathrm{L}^{-1} \quad(\mathrm{Lz} 1079) ; \quad \mathrm{K}^{+}=0.14-0.19 \mathrm{mg} \mathrm{L}^{-1}$ (Lz1024), $0.18-0.22 \mathrm{mg} \mathrm{L}^{-1}$ (Lz1079). The $\mathrm{pH}$ values of 6.2-6.5 (Lz1024) and 5.7-5.9 (Lz1079) indicate that Lake El'gygytgyn is weakly acidic (Cremer and van de Vijver, 2006).

The Lake El'gygytgyn region today has a mean annual temperature ca. $-10^{\circ} \mathrm{C}$, mean July temperature between +4 and $+8^{\circ} \mathrm{C}$, and average winter lows between -32 and $-36^{\circ} \mathrm{C}$ (Treshnikov, 1985). Mean annual precipitation is ca. $200 \mathrm{~mm} \mathrm{yr}^{-1}$ (Brigham-Grette et al., 2013). In mid-May, snow that covers the frozen lake begins to melt. In the last week of June, a moat is formed along the edge of the lake ice, and complete ice melt occurs in mid-July. The moat is formed by a combination of meltwater accumulation from snow cover on the ice surface and from the surrounding slopes. Solar heating of the shallow shelves ( $<5 \mathrm{~m}$ deep) also contributes to the opening of this moat. During glacial times, when the lake level was lower and shelves were narrower, moats were perhaps much smaller and harder to form (Nolan, 2013).

The vegetation in the Lake El'gygytgyn catchment is a mix of discontinuous and continuous herb-lichen tundra, which forms a more barren landscape compared to the surrounding Chukchi Uplands (Lozhkin and Anderson, 2013). The lake lies in the continuous permafrost zone. In 2003, the active layer was ca. $0.4 \mathrm{~m}$ deep in peaty silt and reached $0.5-0.8 \mathrm{~m}$ in sand and gravel on the slopes (Schwamborn et al., 2012).

The bedrock surrounding the lake basin to the north, west, and east primarily consists of ignimbrites and tuffs of the Pykarvaam and Ergyvaam formations (Bely and Raikevich, 1994; Fig. 1b). The Voronian (ignimbrites, tuffs) and Koekvun' formations (andesite basalts, tuffs, tuffaceous sands), while present, are not as prevalent (Bely and Belaya, 1998; Bely and Raikevich, 1994). The crater rim is composed of hills reaching an altitude of $850-950 \mathrm{~m}$. According to geochemical data reported by Bely and Belaya (1998), the Pykarvaam and Ergyvaam formations are predominantly acidic in composition and plot within the rhyolite field in a total alkali-silica (TAS) diagram (Le Maitre et al., 2002; Fig. 2). Rocks of the Voronian Formation are located in the andesite field, whereas the Koekvun' Formation plots in the basaltic andesite area. Chemical and physical weathering products from these rocks comprise the majority of the clastic deposits in the lake.

\subsection{Lithology and age model}

Three lithofacies (facies A, B, and C) dominate the pelagic Pleistocene sediments of Lake El'gygytgyn (Melles et al., 2011, 2012). These facies reflect different environmental 


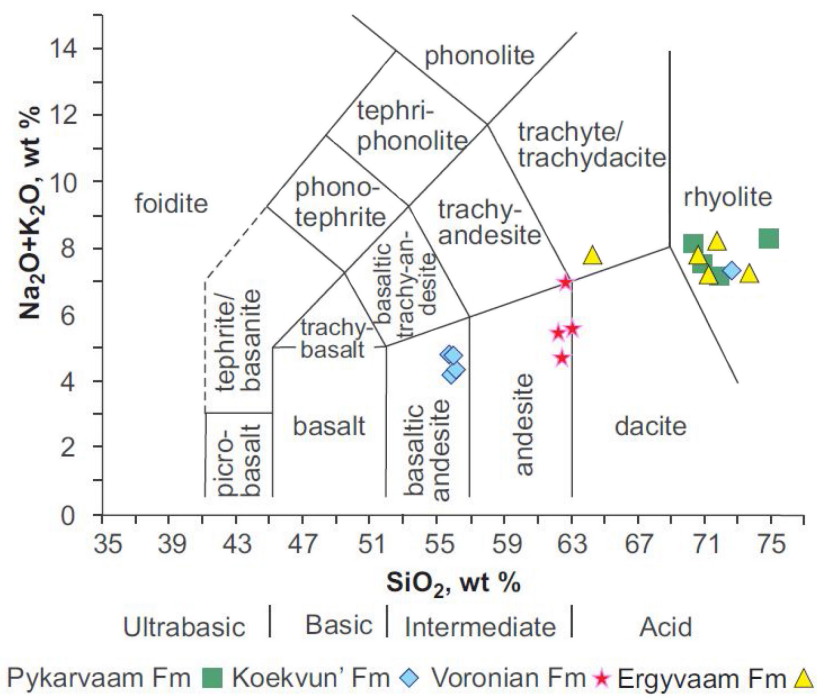

Fig. 2. Diagram of total alkali and silica (Le Maitre et al., 2002) for volcanic rocks from the El'gygytgyn area. Geochemical data are from Bely and Belaya (1998).

settings and climate modes. Facies A consists of dark gray to black silt and clay, with fine laminae $(<5 \mathrm{~mm})$ characterized by a "wavy" structure. This facies is linked to glacial/stadial conditions and the presence of a perennial lake-ice cover. The latter resulted in a stratified water column with anoxic bottom waters, good preservation of the settled organic matter, and dissolution of magnetic minerals.

Facies B is composed of olive-gray to brown silt that is massive to faintly banded. Total organic matter (TOC) is low in this facies, but biogenic silica values and magnetic susceptibility (MS) are moderate to high. Sediment structure suggests the presence of minor bioturbation and oxygenated bottom waters (Melles et al., 2011, 2012).

Facies $\mathrm{C}$ is defined by a distinct reddish brown appearance and the presence of laminations that are faint, pale white in color and have a millimeter-to-centimeter scale thickness. This facies corresponds to times of warm super interglacial climate (Melles et al., 2012).

The age-depth model for the ICDP 5011-1 composite core is based on variations in several parameters including magnetostratigraphy and select sediment proxy data ( $\mathrm{Si} / \mathrm{Ti}, \mathrm{MS}$, TOC). The lake data were compared with trends in the LR04 marine isotope stack (Lisiecki and Raymo, 2005) and curves of regional spring and summer insolation (Laskar et al., 2004) to achieve an age scheme for the El'gygytgyn record. See Melles et al. (2012) and Nowaczyk et al. (2013) for more details.

\section{Methods}

Sediments for elemental analyses were taken at $2 \mathrm{~cm}$ intervals between 5.67 and $19.99 \mathrm{~m}$ depth in the composite core 5011-1 (Melles et al., 2011, 2012), yielding a total of 617 samples. Within this interval, deposits thought to be the result of mass movements (Sauerbrey et al., 2013) were omitted (Wennrich et al., 2013b). After freeze-drying, the samples were sieved to remove particles $>0.25 \mathrm{~mm}$, which mostly consisted of rock fragments and vivianite nodules. The nodules were weighed. The major elements in the sieved sediments were analyzed using a multichannel WDXRF spectrometer SRM-25 (USSR) and a S4 Pioneer X-ray fluorescence spectrometer (Bruker, Germany). For analyses using the SRM-25 spectrometer, dry sediment samples were fused with a lithium tetraborate $\left(\mathrm{Li}_{2} \mathrm{~B}_{4} \mathrm{O}_{7}\right)$ flux having a mass ratio of $1: 1$. These samples were subsequently ground and layered with boric acid. X-ray fluorescence of $K \alpha$ lines was determined over a measurement time of $100 \mathrm{~s}$ by exposing the alloy to X-radiation generated by a Rh anode set to $50 \mathrm{kV}$ and $40 \mathrm{~mA}$. Elemental compositions were determined using the fundamental parameters method (Borkhodoev, 2002). Wavelength dispersive X-ray fluorescence analyses of elements with a Pioneer S4 spectrometer were conducted using a Rh anode at a voltage of $50 \mathrm{kV}$ and a current of $40 \mathrm{~mA}$ as primary radiation. The Pioneer S4 was equipped with a LiF200 analyzing crystal, a flow-proportional detector, and a collimator with an angular aperture of $0.23^{\circ}$ to register the analytical signal. The background near the $\mathrm{Ce} \mathrm{L} \beta_{1}$ line was measured on the short wavelength side, whereas the background near the $\mathrm{Ba} L \beta_{1}$ line was measured on the long wavelength side.

Rare elements were ascertained using a VRA-30 XRF spectrometer (Germany). Sediment powders were measured with a cup having a $25 \mu \mathrm{m}$-thick mylar window. The intensity of the $\mathrm{Rb}, \mathrm{Sr}, \mathrm{Y}, \mathrm{Zr}$, and $\mathrm{Nb} K \alpha$ lines was determined following radiation with a $\mathrm{Rh}$ anode at $50 \mathrm{kV}$ and $40 \mathrm{~mA}$. The elemental composition was calculated using the standard background method. The Compton scattered $K \alpha$ lines of the $\mathrm{X}$ ray tube target were utilized to correct for matrix effects and to determine the background radiation (Borkhodoev, 1998). The lower detection limits of elemental determination with this method were $4 \mathrm{ppm}$ for $\mathrm{Rb}, \mathrm{Y}, \mathrm{Sr}$ and $\mathrm{Zr}$, and $3 \mathrm{ppm}$ for $\mathrm{Nb}$.

The relative organic matter content was estimated by loss on ignition (LOI). Samples were heated to temperatures of 550 and $1000^{\circ} \mathrm{C}$ for over one hour, and the LOI was calculated from the measured weight loss (Heiri et al., 2001).

Weight low-field AC magnetic susceptibility of discrete samples was measured on a kappabridge MFK1-FA (AGICO Ltd., Brno, Czech Republic). Hysteresis parameters, including the saturation magnetization $\left(J_{\mathrm{S}}\right)$, induced magnetization $\left(J_{\mathrm{i}}\right)$, saturation remanence $\left(J_{\mathrm{rs}}\right)$, coercive force $\left(B_{\mathrm{c}}\right)$, and remanence coercivity $\left(B_{\mathrm{cr}}\right)$ were established with an automatic coercive spectrometer (Burov et al., 1986). The relative content of the paramagnetic component of magnetization $\left(J_{\mathrm{p}}\right)$ was calculated by the formula $\left[J_{\mathrm{i}}(\right.$ at $500 \mathrm{mT})-J_{\mathrm{s}}$ (ferromagnetic component) $] / J_{\mathrm{i}}$ (at $500 \mathrm{mT}$ ). 
Table 1. Pearson $(r)$ correlation coefficients for major and trace elemental analyses from Lake El'gygytgyn sediments.

\begin{tabular}{|c|c|c|c|c|c|c|c|c|c|c|c|c|c|c|c|c|}
\hline & $\mathrm{SiO}_{2}$ & $\mathrm{Al}_{2} \mathrm{O}_{3}$ & $\mathrm{TiO}_{2}$ & $\mathrm{Fe}_{2} \mathrm{O}_{3}$ & $\mathrm{MnO}$ & $\mathrm{MgO}$ & $\mathrm{CaO}$ & $\mathrm{Na}_{2} \mathrm{O}$ & $\mathrm{K}_{2} \mathrm{O}$ & $\mathrm{P}_{2} \mathrm{O}_{5}$ & $\mathrm{Rb}$ & $\mathrm{Zr}$ & $\mathrm{Sr}$ & $\mathrm{Ba}$ & $\mathrm{Ni}$ & $\mathrm{Cr}$ \\
\hline $\mathrm{SiO}_{2}$ & 1.00 & & & & & & & & & & & & & & & \\
\hline $\mathrm{Al}_{2} \mathrm{O}_{3}$ & -0.89 & 1.00 & & & & & & & & & & & & & & \\
\hline $\mathrm{TiO}_{2}$ & -0.74 & 0.62 & 1.00 & & & & & & & & & & & & & \\
\hline $\mathrm{Fe}_{2} \mathrm{O}_{3}$ & -0.82 & 0.49 & 0.69 & 1.00 & & & & & & & & & & & & \\
\hline $\mathrm{MnO}$ & -0.26 & 0.01 & 0.22 & 0.51 & 1.00 & & & & & & & & & & & \\
\hline $\mathrm{MgO}$ & -0.81 & 0.77 & 0.83 & 0.65 & 0.08 & 1.00 & & & & & & & & & & \\
\hline $\mathrm{CaO}$ & 0.12 & -0.04 & -0.34 & -0.38 & -0.29 & -0.29 & 1.00 & & & & & & & & & \\
\hline $\mathrm{Na}_{2} \mathrm{O}$ & -0.04 & 0.02 & 0.10 & -0.17 & -0.12 & -0.14 & 0.55 & 1.00 & & & & & & & & \\
\hline $\mathrm{K}_{2} \mathrm{O}$ & -0.47 & 0.64 & -0.06 & 0.01 & -0.31 & 0.22 & 0.49 & 0.31 & 1.00 & & & & & & & \\
\hline $\mathrm{P}_{2} \mathrm{O}_{5}$ & -0.21 & -0.16 & 0.03 & 0.56 & 0.55 & -0.01 & -0.25 & -0.22 & -0.29 & 1.00 & & & & & & \\
\hline $\mathrm{Rb}$ & -0.66 & 0.82 & 0.19 & 0.22 & -0.19 & 0.47 & 0.18 & 0.02 & 0.89 & -0.22 & 1.00 & & & & & \\
\hline $\mathrm{Zr}$ & -0.63 & 0.55 & 0.82 & 0.48 & 0.13 & 0.55 & 0.01 & 0.53 & 0.22 & -0.09 & 0.25 & 1.00 & & & & \\
\hline $\mathrm{Sr}$ & 0.19 & -0.07 & -0.38 & -0.49 & -0.34 & -0.42 & 0.83 & 0.71 & 0.56 & -0.31 & 0.23 & 0.08 & 1.00 & & & \\
\hline $\mathrm{Ba}$ & -0.47 & 0.55 & 0.13 & 0.07 & -0.20 & 0.21 & 0.56 & 0.49 & 0.86 & -0.22 & 0.69 & 0.38 & 0.62 & 1.00 & & \\
\hline $\mathrm{Ni}$ & -0.12 & 0.07 & 0.21 & 0.14 & 0.09 & 0.12 & -0.02 & 0.06 & -0.04 & 0.01 & -0.04 & 0.22 & -0.05 & 0.01 & 1.00 & \\
\hline $\mathrm{Cr}$ & -0.38 & 0.25 & 0.60 & 0.47 & 0.21 & 0.50 & -0.32 & -0.09 & -0.20 & 0.12 & -0.04 & 0.42 & -0.41 & -0.11 & 0.78 & 1.00 \\
\hline
\end{tabular}

Bold numbers marks the high correlation coefficients.

Principal component analysis (PCA) was used to reduce the dimensions of a multivariate data set using the PAST software program (Hammer et al., 2001). This analysis was performed on a correlation matrix of major and trace elements, CIA, PIA, CIW, LOI, Rb/Sr, and magnetic susceptibility.

\section{Results and discussion}

The geochemical characteristics of lacustrine sediments depend on many factors, including the (1) chemical composition of the provenance; (2) physical and chemical weathering processes in the catchment; (3) tectonic and eolian activity; (4) sorting during sediment transport and sedimentation; and (5) post-depositional diagenetic changes (e.g., Fralick and Kronberg, 1997).

\subsection{Elemental concentrations}

Element distributions for the 5.67 to $19.99 \mathrm{~m}$ interval of the Lake El'gygytgyn core display both significant parallel and opposite variations. Strong negative correlations occur between $\mathrm{SiO}_{2}$ and $\mathrm{Al}_{2} \mathrm{O}_{3}(r=-0.89), \mathrm{SiO}_{2}$ and $\mathrm{Fe}_{2} \mathrm{O}_{3}$ $(r=-0.82)$, and $\mathrm{SiO}_{2}$ and $\mathrm{MgO}(r=-0.81)$. Conversely, strong positive correlations were noted for $\mathrm{Al}_{2} \mathrm{O}_{3}$ and $\mathrm{Rb}$ $(r=0.82), \mathrm{TiO}_{2}$ and $\mathrm{MgO}(r=0.83), \mathrm{TiO}_{2}$ and $\mathrm{Zr}(r=0.82)$, $\mathrm{CaO}$ and $\mathrm{Sr}(r=0.83), \mathrm{K}_{2} \mathrm{O}$ and $\mathrm{Rb}(r=0.89), \mathrm{K}_{2} \mathrm{O}$ and $\mathrm{Ba}$ $(r=0.86)$, and $\mathrm{Cr}$ and $\mathrm{Ni}(r=0.78)$ (Table 1$)$.

The first PC axis of the PCA results explains $40 \%$ of the total variance. It is positively correlated with $\mathrm{Al}_{2} \mathrm{O}_{3}, \mathrm{TiO}_{2}$, $\mathrm{Fe}_{2} \mathrm{O}_{3}, \mathrm{MgO}, \mathrm{Rb} / \mathrm{Sr}, \mathrm{CIA}, \mathrm{PIA}, \mathrm{CIW}, \mathrm{Ni}$, and $\mathrm{Cr}$ and negatively correlated with $\mathrm{SiO}_{2}$. The second $\mathrm{PC}$ axis explains an additional $24 \%$ of the variability and is characterized by positive loadings of $\mathrm{Ba}, \mathrm{K}, \mathrm{Rb}, \mathrm{Zr}, \mathrm{Na}_{2} \mathrm{O}, \mathrm{CaO}, \mathrm{MS}$, and $\mathrm{Sr}$. It is negatively correlated with $\mathrm{P}_{2} \mathrm{O}_{5}, \mathrm{MnO}$, and LOI. These results indicate the presence of three main data groups. $\mathrm{SiO}_{2}$ is

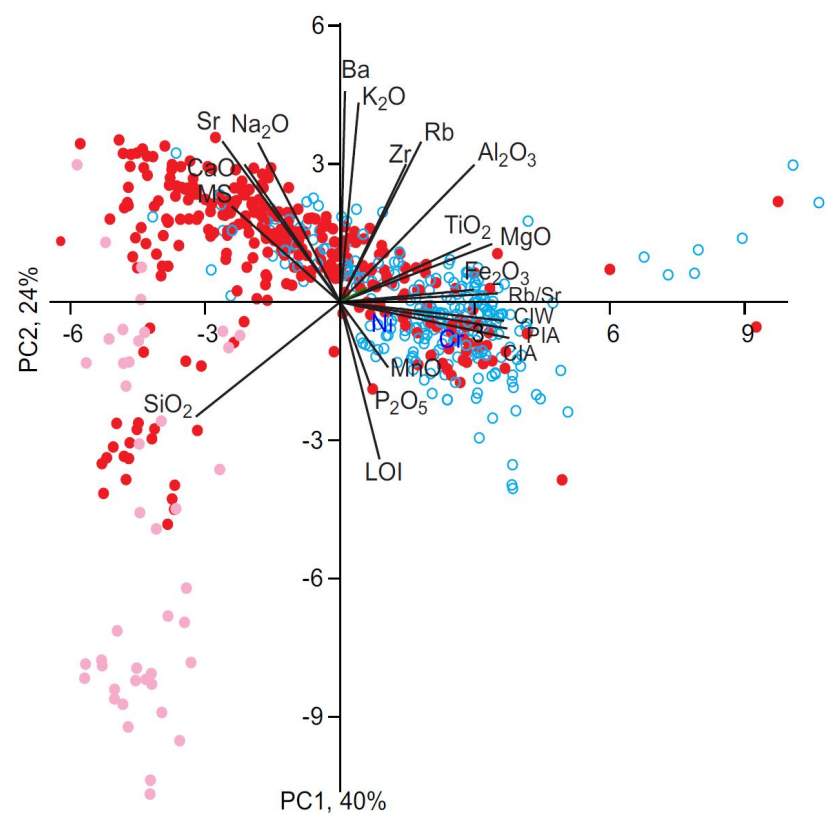

Fig. 3. Principal component analysis of the Lake El'gygytgyn sediments. Red, blue and rose symbols are samples from interglacial, glacial, and super interglacial sediments, respectively.

clearly related to the super interglacial sediments, while $\mathrm{Ba}$, $\mathrm{K}, \mathrm{Rb}, \mathrm{Zr}, \mathrm{Na}_{2} \mathrm{O}, \mathrm{CaO}, \mathrm{MS}$, and $\mathrm{Sr}$ are related to the interstadial sediments. $\mathrm{Al}_{2} \mathrm{O}_{3}, \mathrm{TiO}_{2}, \mathrm{Fe}_{2} \mathrm{O}_{3}, \mathrm{MgO}, \mathrm{Rb} / \mathrm{Sr}, \mathrm{CIA}$, PIA, CIW, Ni, and $\mathrm{Cr}$ are associated with glacial sediments (Fig. 3).

The elemental record from Lake El'gygytgyn can be divided into two groups or geochemical zones based on the variability of the inorganic compounds, elemental ratios, and LOI (Fig. 4). Each group is affected by different environmental conditions and climates associated with glacial/stadial or 


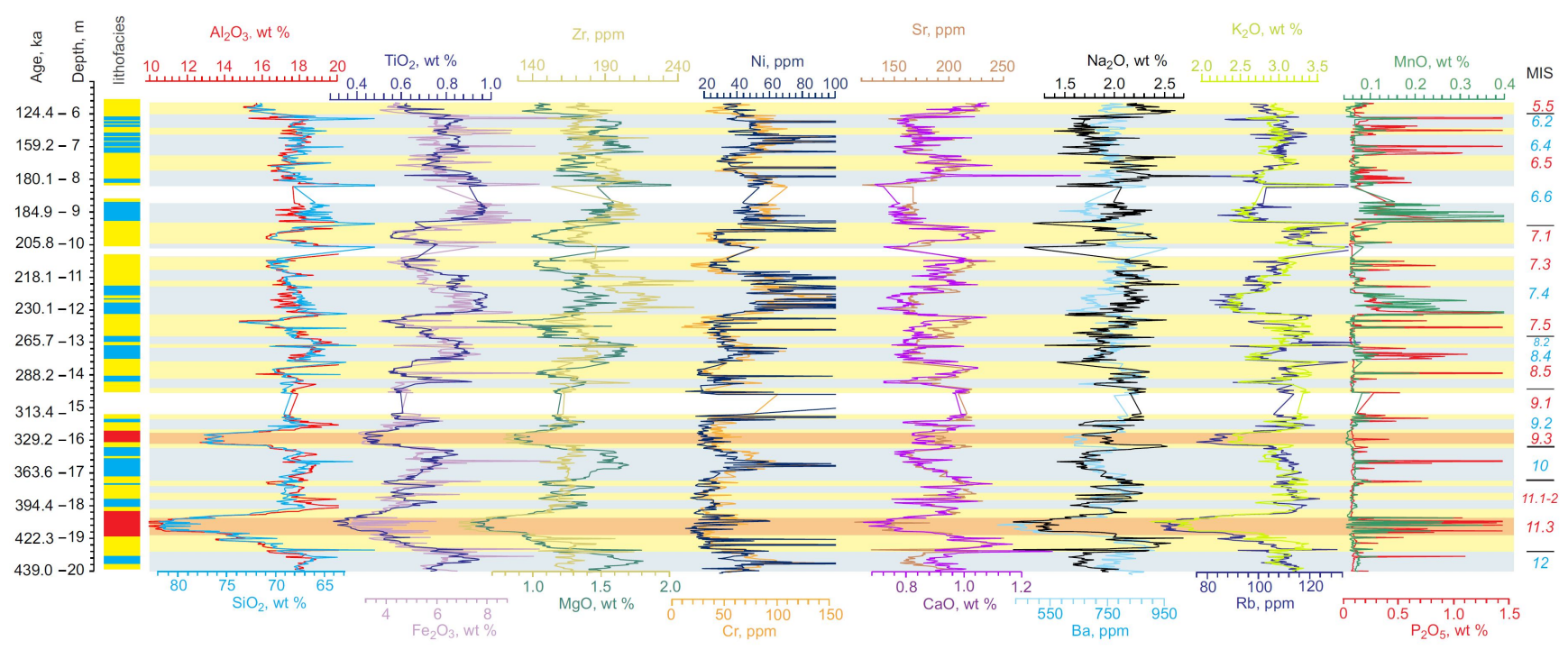

Fig. 4. Graphs of selected elements plotted by depth and age. Yellow, orange and blue bars represent interglacials, super interglacials, and glacials, respectively. Marine isotopic stages (MIS) follow Bassinot et al. (1994). Note that $\mathrm{SiO}_{2}$ is plotted on a reversed scale. Lithofacies A, $\mathrm{B}$ and $\mathrm{C}$ are shown in blue, yellow, and red, respectively.

interglacial periods. These zones were correlated with marine isotope stages based on the age model developed for the El'gygytgyn record (Nowaczyk et al., 2007, 2013; Melles et al., 2012). Note that the age model (Melles et al., 2012; Nowaczyk et al., 2013) was used to help identify specific isotope stages, but boundaries for stages and substages were defined according to the inorganic geochemical data. Arabic numerals for the stages and substages in the figures and text follow Bassinot et al. (1994).

\section{2 $\mathrm{SiO}_{2}$}

The total content of $\mathrm{SiO}_{2}$ is a function of both inorganic and biogenic silica. The amount of BSi varies from less than $5 \%$ up to $56.1 \%$ in the Quaternary sediment record of Lake El'gygytgyn (Melles et al., 2012). In cold stages, $\mathrm{SiO}_{2}$ ranges between 56.98 and $70.81 \%$ (average $67.12 \%$ ), which is notably lower than in the volcanic rocks of the Pykarvaam and Ergyvaam formations (71.01\%). Within the El'gygytgyn warm stages $\mathrm{SiO}_{2}$ averages $70.60 \%$. Maximum $\mathrm{SiO}_{2}$ values for the entire sequence were registered between 18.41-18.77 and $15.77-16.11 \mathrm{~m}$, with peaks of 80.49 and $76.30 \%$, respectively (Fig. 4). According to the age-depth model these horizons correlate with MIS 11.3 (430-390 ka) and MIS 9.3 (340-320 ka). The $\mathrm{SiO}_{2}$ enrichment in these zones is caused by elevated BSi and represents levels of high primary productivity in the lake (Cunningham et al., 2013; Vogel et al., 2013). The interval corresponding to MIS 11 exhibits the greatest peak in diatom concentrations (Snyder et al., 2013).

The $\mathrm{Si} / \mathrm{Ti}$ ratio is positively correlated with biogenic silica. This ratio has been previously used as a relative indicator of the biogenic component in sediments of Lake Malawi (Brown et al., 2007), Lake Baikal (Tanaka et al., 2007), and Lake El'gygytgyn (Melles et al., 2012).

Large-scale variations in the oxides $\mathrm{SiO}_{2}$ and $\mathrm{TiO}_{2}$ indicate a generally strong negative correlation $(r=-0.74$; Table 1). A strong linear correlation $\left(R^{2}=0.8\right)$ is especially valid for samples from MIS 11.3 and 9.3 and less so for MIS 7.1 and 5.5, where $\mathrm{SiO}_{2}$ exceeds $71 \%$ (Fig. 5a). These results indicate that BSi dilution by clastic input was significant during the warmest interglacials. The linear correlation between $\mathrm{SiO}_{2}$ and $\mathrm{TiO}_{2}$ is very poor $\left(R^{2}=0.17\right)$ in interstadial samples and is essentially nonexistent $\left(R^{2}=0.07\right)$ for glacial sediments. This pattern suggests only negligible or no dilution of BSi during cooler episodes in the El'gygytgyn record (Fig. 5a).

The $\mathrm{SiO}_{2} / \mathrm{Al}_{2} \mathrm{O}_{3}$ ratio most resembles the $\mathrm{SiO}_{2} / \mathrm{TiO}_{2}$ ratio $\left(r=0.89\right.$; Fig. 6). $\mathrm{SiO}_{2} / \mathrm{Al}_{2} \mathrm{O}_{3}$ ratios for interglacial and glacial sediments average 4.45 and 3.72, respectively, with a high linear correlation between $\mathrm{SiO}_{2}$ and $\mathrm{Al}_{2} \mathrm{O}_{3}$ for interglacial sediments $\left(R^{2}=0.88\right)$ and a poor correlation for glacial sediments $\left(R^{2}=0.26\right.$; Fig. $\left.5 \mathrm{c}\right)$.

A decrease in the $\mathrm{SiO}_{2} / \mathrm{Al}_{2} \mathrm{O}_{3}$ ratio can be related either to a decrease in grain size or a lower textural maturity (e.g., Weltje and von Eynatten, 2004). Von Eynatten et al. (2012) point out that mechanical processes, such as comminution, impact sediment composition. They further showed that increases in $\mathrm{Al}_{2} \mathrm{O}_{3}$ and decreases in $\mathrm{SiO}_{2}$ concentrations occur with finer grain sizes. Thus, the low $\mathrm{SiO}_{2} / \mathrm{Al}_{2} \mathrm{O}_{3}$ ratios in glacial sediments of Lake El'gygytgyn combined with an absence of $\mathrm{A}_{2} \mathrm{O}_{3}$ dilution by $\mathrm{BSi}$ indicate that they consist of more fine-grained material as compared with either interstadial or interglacial sediments. This conclusion is supported 

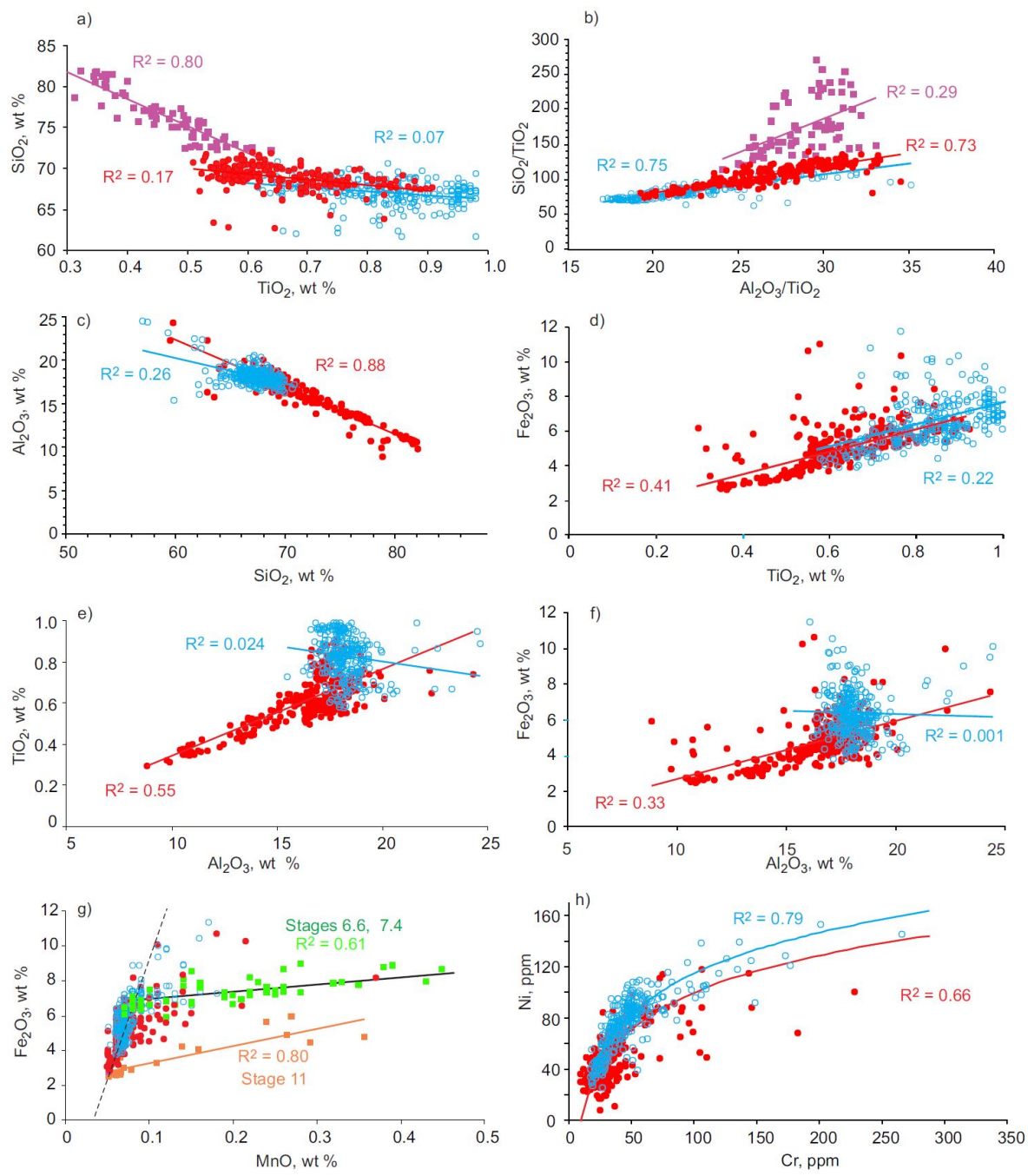

Fig. 5. Scatterplots of: (a) $\mathrm{SiO}_{2}$ versus $\mathrm{TiO}_{2} ;$ (b) $\mathrm{SiO}_{2} / \mathrm{TiO}_{2}$ versus $\mathrm{Al}_{2} \mathrm{O}_{3} / \mathrm{TiO}_{2} ;$ (c) $\mathrm{Al}_{2} \mathrm{O}_{3}$ versus $\mathrm{SiO}_{2} ;$ (d) $\mathrm{Fe}_{2} \mathrm{O}_{3}$ versus $\mathrm{TiO}_{2}$; (e) $\mathrm{TiO}_{2}$ versus $\mathrm{Al}_{2} \mathrm{O}_{3}$; (f) $\mathrm{Fe}_{2} \mathrm{O}_{3}$ versus $\mathrm{Al}_{2} \mathrm{O}_{3}$; (g) $\mathrm{Fe}_{2} \mathrm{O}_{3}$ versus $\mathrm{MnO}$; and (h) $\mathrm{Ni}$ versus $\mathrm{Cr}$. Red (blue) symbols indicate interglacial (glacial) samples. Violet squares are samples where $\mathrm{SiO}_{2}$ content exceeds $71 \%$. Orange squares indicate samples from MIS 11, whereas green squares are samples from MIS 6.6 and 7.4.

by grain-size analysis, which shows higher clay to fine silt content during glacial times (Francke et al., 2013). In contrast, a higher mean $\mathrm{SiO}_{2} / \mathrm{Al}_{2} \mathrm{O}_{3}$ ratio of 4.70 obtained from bedrock samples of the Pykarvaam and Ergyvaam formations indicates the lower maturity of the fresh rocks as compared to the lake sediments.

\section{3 $\mathrm{TiO}_{2}, \mathrm{Al}_{2} \mathrm{O}_{3}, \mathrm{Fe}_{2} \mathrm{O}_{3}$}

In lacustrine environments, $\mathrm{Ti}$ and $\mathrm{Al}$ have been shown to be good measures of the intensity of detrital input (e.g., Whitlock et al., 2008). Mean values of $\mathrm{TiO}_{2}$ and $\mathrm{Al}_{2} \mathrm{O}_{3}$ in the dominant rocks from both the Pykarvaam and Ergyvaam formations are 0.36 and $15.15 \%$, respectively. Concentrations of $\mathrm{TiO}_{2}$ and $\mathrm{Al}_{2} \mathrm{O}_{3}$ are enriched in the El'gygytgyn glacial sediments (Fig. 4). The mean content of $\mathrm{Al}_{2} \mathrm{O}_{3}$ in the interglacial and glacial intervals is 16.36 and $18.08 \%$, respectively. $\mathrm{TiO}_{2}$ content varies between 0.29 and $0.91 \%$ (mean 0.61) in the interglacial sediments and between 0.57 and $0.98 \%$ (mean 0.82) in the glacial sediments. $\mathrm{TiO}_{2}$ content seems to be controlled primarily by grain-size variations. Thus, Ti should be concentrated mainly in the fine fraction, a conclusion that is supported by the lower $\mathrm{TiO}_{2}$ concentrations in the bedrock samples. Ti enrichment has also been documented in silt- and clay-size fractions of weathered granitic rocks in Spain (Taboada et al., 2006) and in Archaean rocks in Canada (Fralick and Kronberg, 1997).

The $\mathrm{TiO}_{2} / \mathrm{Al}_{2} \mathrm{O}_{3}$ (or $\mathrm{Al}_{2} \mathrm{O}_{3} / \mathrm{TiO}_{2}$ ) ratio has often been used as an indicator of sediment provenance, but it is also a good measure of the degree of sediment alteration (Migdisov, 1960; Young and Nesbitt, 1998; Yudovich and Ketris, 2011). The $\mathrm{TiO}_{2} / \mathrm{Al}_{2} \mathrm{O}_{3}$ ratio in the El'gygytgyn 


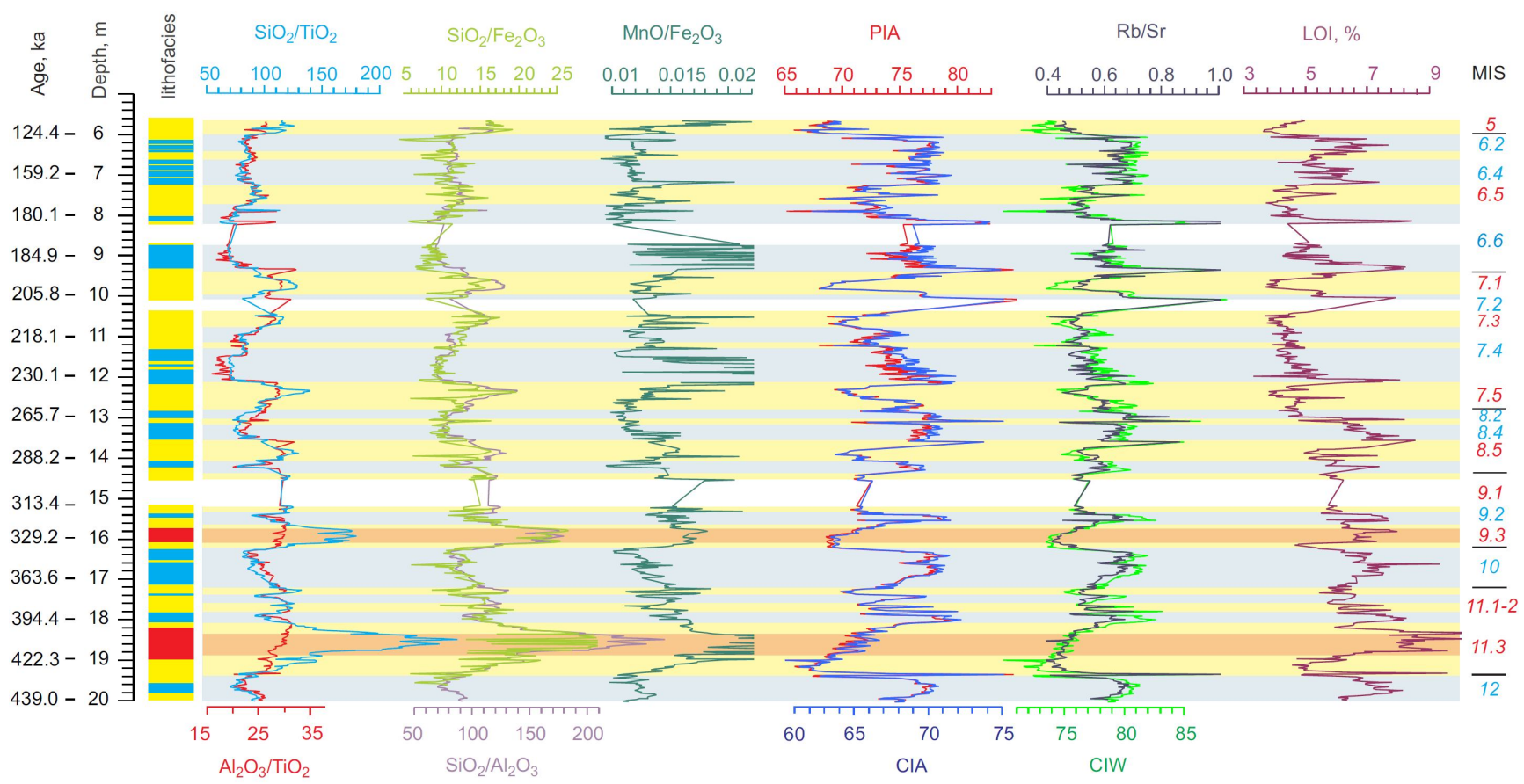

Fig. 6. Distribution of selected geochemical indices and ratios plotted by depth and age. Yellow, orange and blue bars represent interglacials, super interglacials and glacials, respectively. Marine isotopic stages (MIS) follow Bassinot et al. (1994). Lithofacies A, B and C are shown by blue, yellow, and red, respectively.

samples averages 0.037 and 0.045 in warm-stage and coldstage sediments, respectively, and 0.032 in unweathered volcanic rocks. The $\mathrm{Al}_{2} \mathrm{O}_{3}$ versus $\mathrm{TiO}_{2}$ diagram shows a rather straight, linear trend for interglacial sediments $\left(R^{2}=0.55\right)$, whereas cold sediments have a scattered, nearly vertical distribution $\left(R^{2}=0.024\right)$ (Fig. 5e). We suggest that the higher $\mathrm{TiO}_{2} / \mathrm{Al}_{2} \mathrm{O}_{3}$ ratios observed in glacial sediments are due to an enrichment in $\mathrm{TiO}_{2}$ in the finer-grained sediments, as mentioned above. It may relate to the concentration of biotite as noted by Young and Nesbit (1998) for Baffin Island sediments.

The glacial/interstadial and interglacial samples, with the exception of those from the super interglacials, display a strong positive correlation between $\mathrm{SiO}_{2} / \mathrm{TiO}_{2}$ and $\mathrm{Al}_{2} \mathrm{O}_{3} / \mathrm{TiO}_{2}$ ratios $\left(R^{2}=0.73-0.75\right.$, Figs. 5a and 6). In intervals where fluctuations in the $\mathrm{Al}_{2} \mathrm{O}_{3} / \mathrm{TiO}_{2}$ and the $\mathrm{SiO}_{2} / \mathrm{TiO}_{2}$ ratios coincide, the dilution of $\mathrm{TiO}_{2}$ and $\mathrm{Al}_{2} \mathrm{O}_{3}$ by $\mathrm{BSi}$ is supposed to be absent or negligible (Fig. 6).

The $\mathrm{Fe}_{2} \mathrm{O}_{3} / \mathrm{Al}_{2} \mathrm{O}_{3}$ ratio averages 0.30 and 0.35 for interglacials and glacials, respectively. However, the value is lower in volcanic rocks $(0.28)$ that surround the lake. The $\mathrm{Fe}_{2} \mathrm{O}_{3}-\mathrm{Al}_{2} \mathrm{O}_{3}$ diagram exhibits a weak linear correlation during warm stages $\left(R^{2}=0.33\right)$, whereas glacial sediments display a large scatter $\left(R^{2}=0.001 ;\right.$ Fig. $\left.4 \mathrm{f}\right)$. Fe behaves in a similar fashion to $\mathrm{Ti}$, as evident in the parallel trends of $\mathrm{TiO}_{2}$ and $\mathrm{Fe}_{2} \mathrm{O}_{3}, \mathrm{SiO}_{2} / \mathrm{TiO}_{2}$ and $\mathrm{SiO}_{2} / \mathrm{Fe}_{2} \mathrm{O}_{3}$ and the positive correlation in the $\mathrm{TiO}_{2}-\mathrm{Fe}_{2} \mathrm{O}_{3}$ diagram $\left(R^{2}=0.48\right.$; Figs. 4 , $5 \mathrm{~d}$ and 6).
$\mathrm{Fe}$ and $\mathrm{Ti}$ are the main elements in ferromagnetic minerals found in oxides, such as magnetite and titanomagnetite. In Lake El'gygytgyn sediments, the majority of the iron oxides are titanomagnetites that include $\mathrm{Al}, \mathrm{Si}$, and $\mathrm{Mn}$ impurities. Some titanomagnetites have characteristic cracks in the grains, which indicate low-temperature maghemitization. Other titanomagnetites are oxidized at high temperatures, displaying lamellae of ilmenite and titanium magnetite. Chromite, ilmenite, and rutile were also found in the sediments.

To investigate the $\mathrm{Fe}$ and $\mathrm{Ti}$ mineralogy in Lake El'gygytgyn sediments, we examined the correspondence of both elements to various magnetic parameters. During glacial periods, sediments exhibit high $\mathrm{Fe}_{2} \mathrm{O}_{3}$ and $\mathrm{TiO}_{2}$ but low MS; interglacial samples display the opposite pattern. Consequently, data on the $\mathrm{Fe}_{2} \mathrm{O}_{3}-\mathrm{MS}$ and $\mathrm{TiO}_{2}-\mathrm{MS}$ diagrams show a scattered distribution (Fig. 7a, b) with low negative correlation coefficients $(r)$ of -0.28 and -0.43 for $\mathrm{Fe}_{2} \mathrm{O}_{3}$ versus MS, and $\mathrm{TiO}_{2}$ versus MS, respectively. This contradicts the idea that $\mathrm{Ti}$ and $\mathrm{Fe}$ were enriched in the detrital heavy-mineral fraction, which is mirrored by a generally positive correlation of $\mathrm{TiO}_{2}$ and $\mathrm{Fe}_{2} \mathrm{O}_{3}$ to MS (e.g., Ortega et al., 2006; Parker et al., 2006; Reynolds et al., 2004; Vegas et al., 2010). MS includes both ferrimagnetic and paramagnetic components that can be distinguished by determining the induced magnetization.

$\mathrm{TiO}_{2}$ and $\mathrm{Fe}_{2} \mathrm{O}_{3}$ yield only a very poor correlation with the ferromagnetic component $\left(J_{\mathrm{f}}\right)$ (Fig. $7 \mathrm{c}, \mathrm{d}$ ), but 

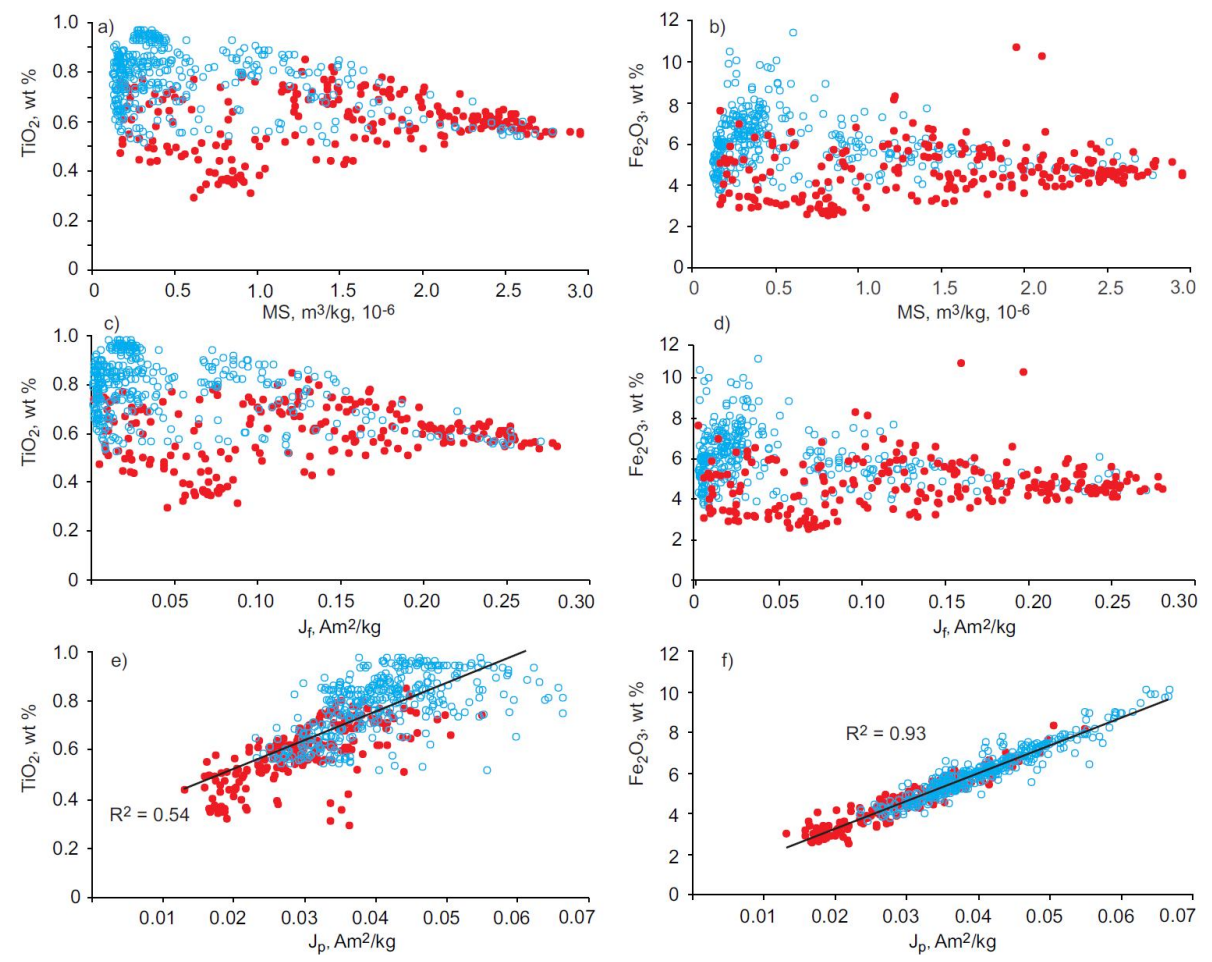

Fig. 7. Diagrams showing variations in $\mathrm{TiO}_{2}$ and $\mathrm{Fe}_{2} \mathrm{O}_{3}$ versus magnetic susceptibility and ferromagnetic and paramagnetic components of induced magnetization. Red (blue) symbols indicate samples from interglacial (glacial) sediments.

a strong correlation with the paramagnetic component $\left(J_{\mathrm{p}}\right)$ of induced magnetization (Fig. 7e, f). Hence, high $\mathrm{TiO}_{2}$ content in the glacial-age samples can not be attributed to titaniferous minerals such as titanomagnetite, rutile, or ilmenite, which are typically found in lake sediments. These minerals would evoke a positive correlation of $\mathrm{TiO}_{2}\left(\mathrm{Fe}_{2} \mathrm{O}_{3}\right)$ with MS and $J_{\mathrm{f}}$. Most $\mathrm{Ti}$ and $\mathrm{Fe}$, especially during cold intervals, should be concentrated in paramagnetic $\mathrm{Fe}$ - or Ti-bearing minerals. These minerals include chlorite $\left(\mathrm{Mg}_{3.5} \mathrm{Fe}_{1.5} \mathrm{Al}_{2} \mathrm{Si}_{3} \mathrm{O}_{14}\right)$, with $\mathrm{Fe}$ and $\mathrm{Mg}$ acting as the main elements (Boyle, 2002), or biotite $\left(\mathrm{K}_{0.9} \mathrm{Na}_{0.01}\right)\left(\mathrm{Mg}_{1.5} \mathrm{Fe}_{1.1}\right)\left(\mathrm{Al}_{0.05} \mathrm{Ti}_{0.2}\right)\left[\mathrm{Si}_{2.9} \mathrm{Al}_{1.1} \mathrm{O}_{10}\right](\mathrm{OH})_{2}$ (e.g., Just and Kontny, 2012). The importance of chlorite as a primary iron carrier in glacial sediments is indicated by the positive correlation of $\mathrm{TiO}_{2}$ to $\mathrm{MgO}(r=0.83)$ and $\mathrm{Fe}_{2} \mathrm{O}_{3}$ with $\mathrm{MgO}(r=0.65)$. This conclusion is supported by a clay mineral study of Lake El'gygytgyn sediments of the past $65 \mathrm{ka}$, indicating that cold stages are typically enriched in chlorite (Asikainen et al., 2007).

\section{$3.4 \mathrm{P}_{2} \mathrm{O}_{5}, \mathrm{MnO}$}

Phosphorous and manganese oxide concentrations have a relatively strong linear relationship $(r=0.55)$ in the El'gygytgyn record. Both elements show strong positive correlations with $\mathrm{Fe}_{2} \mathrm{O}_{3}$ (Table 1). Peaks in $\mathrm{P}_{2} \mathrm{O}_{5}$ and $\mathrm{MnO}$ occurred in the early parts of cold stages (MIS 8.4, 7.4, 6.6,
6.4, and 6.2), with a single exception (18.85-18.39 m) that corresponds to the super interglacial MIS 11.3 (Fig. 4). All of these intervals exhibit high LOI values, which is a proxy for the relative content of organic matter (Fig. 6). $\mathrm{P}_{2} \mathrm{O}_{5}$, $\mathrm{MnO}$, and LOI have strong negative loadings on the PC2 in the PCA diagram (Fig. 3). Similar trends in $\mathrm{MnO}, \mathrm{P}_{2} \mathrm{O}_{5}$ and $\mathrm{Fe}_{2} \mathrm{O}_{3}$ enrichment are linked to the occurrence of authigenic, fine-grained vivianite, whose formation is primarily controlled by pore waters supersaturated in $\mathrm{Fe}$ and $\mathrm{P}$, anoxic conditions, and the accumulation of organic matter (Sapota et al., 2006). Electron-microprobe analyses reveal the presence of $\mathrm{Fe}_{2} \mathrm{O}_{3}, \mathrm{P}_{2} \mathrm{O}_{5}$ and $\mathrm{MnO}$ in the vivianite nodules. The $\mathrm{Fe}_{2} \mathrm{O}_{3}$ content in these nodules varies from 30.18 to $39.4 \%$ (averaging $35.18 \%$ ), while $\mathrm{P}_{2} \mathrm{O}_{5}$ and $\mathrm{MnO}$ concentrations vary from 21.23 to $29.28 \%$ (averaging $25.02 \%$ ), and from 0.67 to $6.34 \%$ (averaging $2.06 \%$ ), respectively (Minyuk et al., 2013). Mn is described as a typical impurity in Lake Baikal vivianite (Fagel et al., 2005). In a few samples from MIS 6, Fe-Mn aggregates were identified by energy dispersive spectroscopy. Fe and $\mathrm{Mn}$ are sensitive to changes in oxic-anoxic conditions, but these elements show slightly different reactions in each depositional setting. Thus, the $\mathrm{Mn} / \mathrm{Fe}$ (or $\mathrm{Fe} / \mathrm{Mn}$ ) ratio is commonly used as an indicator for palaeo-redox environments (e.g., Davison, 1993; Loizeau et al., 2001; Melles et al., 2012). Low ratios of $\mathrm{MnO} / \mathrm{Fe}_{2} \mathrm{O}_{3}$ dominate in glacial sediments, suggesting anoxic conditions in bottom waters and surface sediment during sedimentation 
Table 2. Pearson $(r)$ correlation coefficients for selective elemental ratios and indices from Lake El'gygytgyn sediments.

\begin{tabular}{|c|c|c|c|c|c|c|c|c|c|c|}
\hline & CIA & CIW & PIA & $\mathrm{Rb} / \mathrm{Sr}$ & $\mathrm{SiO}_{2} / \mathrm{TiO}_{2}$ & $\mathrm{SiO}_{2} / \mathrm{Al}_{2} \mathrm{O}_{3}$ & $\mathrm{Ba} / \mathrm{Sr}$ & LOI & MS & $J_{\mathrm{p}}$ \\
\hline CIA & 1.00 & & & & & & & & & \\
\hline CIW & 0.97 & 1.00 & & & & & & & & \\
\hline PIA & 0.99 & 0.99 & 1.00 & & & & & & & \\
\hline $\mathrm{Rb} / \mathrm{Sr}$ & 0.86 & 0.90 & 0.89 & 1.00 & & & & & & \\
\hline $\mathrm{SiO}_{2} / \mathrm{TiO}_{2}$ & -0.57 & -0.52 & -0.54 & -0.51 & 1.00 & & & & & \\
\hline $\mathrm{SiO}_{2} / \mathrm{Al}_{2} \mathrm{O}_{3}$ & -0.58 & -0.59 & -0.59 & -0.60 & 0.89 & 1.00 & & & & \\
\hline $\mathrm{Ba} / \mathrm{Sr}$ & 0.73 & 0.75 & 0.74 & 0.85 & -0.63 & -0.64 & 1.00 & & & \\
\hline LOI & 0.35 & 0.38 & 0.37 & 0.31 & 0.37 & 0.26 & 0.12 & 1.00 & & \\
\hline MS & -0.66 & -0.57 & -0.61 & -0.44 & 0.29 & 0.18 & -0.35 & -0.43 & 1.00 & \\
\hline$J_{\mathrm{p}}$ & 0.73 & 0.67 & 0.70 & 0.59 & -0.46 & -0.41 & 0.51 & 0.37 & -0.88 & 1.00 \\
\hline
\end{tabular}

(Figs. 5g and 6). Plots of $\mathrm{Fe}_{2} \mathrm{O}_{3}$ and the $\mathrm{MnO} / \mathrm{Fe}_{2} \mathrm{O}_{3}$ ratio show parallel trends during the early intervals of MIS 6.6 and 7.4 and for some levels within MIS 11.3. These are characterized by maxima in $\mathrm{Fe}_{2} \mathrm{O}_{3}$ and in the $\mathrm{MnO} / \mathrm{Fe}_{2} \mathrm{O}_{3}$ ratio. These peaks are accompanied by the occurrence of finegrained vivianite, which suggests the presence of a reducing condition at the sediment-water interface (Mackereth, 1966).

\section{5 $\mathrm{Cr}, \mathrm{Ni}$}

The concentrations of $\mathrm{Cr}$ and $\mathrm{Ni}$ in the sediments of Lake El'gygytgyn range from 8 and $333 \mathrm{ppm}$ (average of 65) and 9 and $1032 \mathrm{ppm}$ (average of 49), respectively. Both elements exhibit similar down-core distributions (Fig. 4) that also are indicated by a strong positive correlation $(r=0.78)$ (Fig. 5h, Table 1). Cr and Ni are generally enriched during the cold stages and in MIS 11.3 but generally are depleted in warm stages (Fig. 4). The cold stages are characterized by high abundances of total organic carbon (Melles et al., 2007, 2012), LOI (Fig. 6), and a higher clay content, suggesting that $\mathrm{Cr}$ and $\mathrm{Ni}$ might be absorbed by either organic matter (e.g., Sharma et al., 2004) or clay minerals (e.g., Das and Haake, 2003; Pistolato et al., 2006). Geochemical analysis of surface sediments from the lake indicates that the main source of $\mathrm{Cr}$ and $\mathrm{Ni}$ is linked to weathering products of basalts and andesite basalts found along the southern shore of Lake El'gygytgyn (Wennrich et al., 2013a).

\subsection{Zr, Rb, Sr, Ba}

This group of elements yield high positive loadings on the first axis of the PCA diagram (Fig. 3). In the portion of the El'gygytgyn record studied in this paper, $\mathrm{Zr}, \mathrm{Rb}$, and $\mathrm{Sr}$ contents vary between 81 and $257 \mathrm{ppm}$ (averaging $172 \mathrm{ppm}$ ), 52 and $154 \mathrm{ppm}$ (averaging $105 \mathrm{ppm}$ ), and 112 and $249 \mathrm{ppm}$ (averaging $187 \mathrm{ppm}$ ), respectively (Fig. 4). The Sr content in the Pykarvaam and Ergyvaam formations, which dominate the lake catchment, averages $285 \mathrm{ppm}$. $\mathrm{Rb}$ shows a high positive correlation with $\mathrm{Al}_{2} \mathrm{O}_{3}(r=0.82)$ and with $\mathrm{K}_{2} \mathrm{O}(r=0.89) . \mathrm{Rb}$ is in general negatively correlated with
$\mathrm{Zr}(r=-0.66)$, except in sediments from super interglacial stages 9.3 and 11.3, when both elements exhibit a parallel distribution presumably due to dilution by extremely high BSi values. $\mathrm{Zr}$ shows a strong positive correlation with $\mathrm{TiO}_{2}$ $(r=0.82)$, and $\mathrm{Sr}$ is positively correlated with $\mathrm{CaO}(r=0.83)$ (Table 1).

The $\mathrm{Rb} / \mathrm{Sr}$ ratios of interglacials and glacials vary from 0.32 to 1.03 (mean $0.52, n=308$ ) and 0.41 to 1.24 (mean $0.62, n=292$ ), respectively. These values are significantly higher then the average $\mathrm{Rb} / \mathrm{Sr}$ ratio of volcanic rock $(0.32, n=18)$ that surrounds Lake El'gygytgyn. This mean value is similar to that from the Upper Continental Crust (mean 0.32; Taylor and McLennan, 1985). Because Sr is a mobile element, it tends to disappear during chemical weathering. Thus, the resulting $\mathrm{Rb} / \mathrm{Sr}$ ratio in weathered rock is greater than that of unweathered rocks (e.g., Dasch, 1969). $\mathrm{Rb} / \mathrm{Sr}$ ratios have been applied to define provenances and to determine the weathering history of different types of deposits, including deep-sea, alluvial, lacustrine, loess, and paleosols (e.g., Gallet et al., 1998; Goldberg et al., 2000). The increased $\mathrm{Rb} / \mathrm{Sr}$ ratios in glacial sediments from Lake El'gygytgyn, as compared to the warm stages and to the surrounding rocks, indicate a systematic $\mathrm{Sr}$ depletion. This depletion may be due to higher alteration and seems to be controlled by grain-size variations (Wennrich et al., 2013b). A similar relationship was reported for sediments in Teletskoe Lake (Kalugin et al., 2007).

$\mathrm{The} \mathrm{Rb} / \mathrm{Sr}$ and $\mathrm{Ba} / \mathrm{Sr}$ ratios show a strong positive correlation (Table 2) and can be used as an indicator of weathering and the intensity of sediment leaching (e.g., Goldberg et al., 2000; Yang et al., 2006; Bokhorst et al., 2009). The Ba/Sr ratios vary from 1.60 to 4.10 (mean $2.41, n=302$ ) during interglacial intervals and between 2.15 and 4.49 (mean 2.72, $n=292$ ) in glacial sediments. The $\mathrm{Ba}$ and $\mathrm{Rb}$ content has a strong positive correlation with $\mathrm{K}_{2} \mathrm{O}$ (Table 1), which suggests a K-feldspar source for these elements (Wennrich et al., 2013a). 

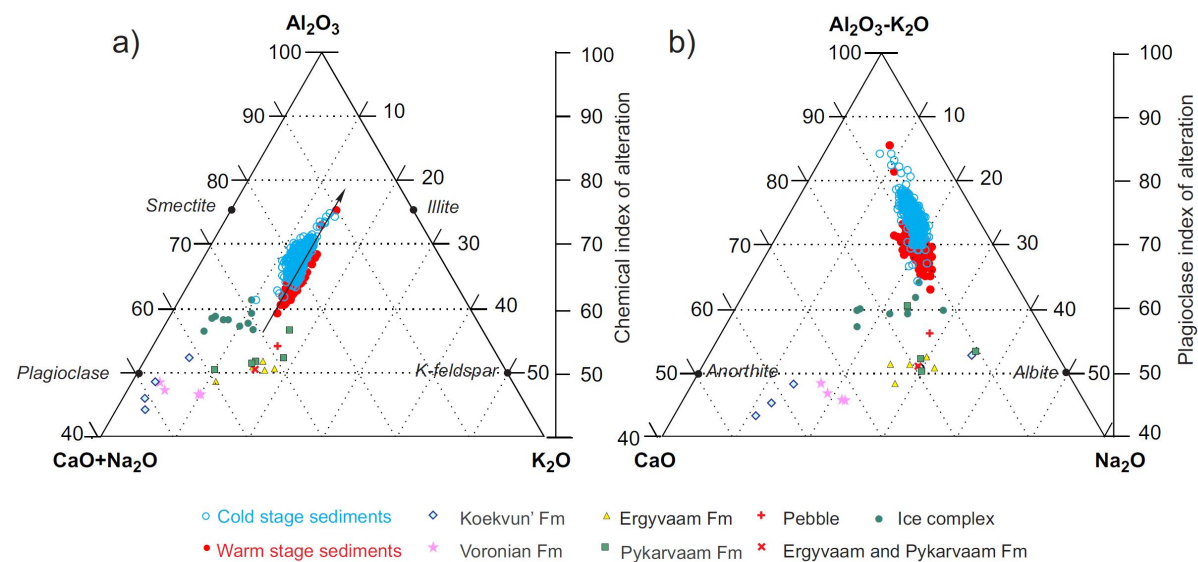

Fig. 8. Ternary diagrams showing weathering trends in volcanic rocks, lake sediments, and ice complexes: (a) $\left(\mathrm{CaO}+\mathrm{Na}_{2} \mathrm{O}\right)-\mathrm{Al}_{2} \mathrm{O}_{3}-\mathrm{K}_{2} \mathrm{O}$ diagram (Nesbitt and Young, 1984); and (b) $\mathrm{CaO}-\left(\mathrm{Al}_{2} \mathrm{O}_{3}-\mathrm{K}_{2} \mathrm{O}\right)-\mathrm{Na}_{2} \mathrm{O}$ diagram (Fedo et al., 1995). Arrow indicates the weathering trends.

\subsection{Geochemical indices}

Estimations of the degree of rock alteration and weathering can be estimated quantitatively using several geochemical indices (e.g., Duzgoren-Aydin et al., 2002; Maslov et al., 2003; Price and Velbel, 2003; Yudovich and Ketris, 2011). Most of these indices are expressed as molecular or weight percentages of various oxides or groups of oxides. During chemical weathering, more labile minerals, such as feldspar and plagioclase, are depleted in $\mathrm{Ca}^{2+}, \mathrm{K}^{+}$and $\mathrm{Na}^{+}$and transformed into minerals that are more stable under surface conditions. As the intensity of weathering increases, rocks and sediments become enriched in $\mathrm{Al}, \mathrm{Ti}, \mathrm{Fe}$, and $\mathrm{Mn}$. In our analyses of the El'gygytgyn core, the distribution of selected indices (Table 2) exhibits parallel or opposite variations as described below (Fig. 6).

\subsubsection{Chemical index of alteration}

The chemical index of alteration (CIA) was defined by Nesbitt and Young (1982) using the molecular proportions:

$\mathrm{CIA}=\left[\mathrm{Al}_{2} \mathrm{O}_{3} /\left(\mathrm{Al}_{2} \mathrm{O}_{3}+\mathrm{CaO}+\mathrm{NaO}+\mathrm{K}_{2} \mathrm{O}\right)\right] \times 100,(1)$

with $\mathrm{CaO}$ being the amount of $\mathrm{CaO}$ incorporated in the silicate fraction of the rock. The CIA measures the proportion of $\mathrm{Al}_{2} \mathrm{O}_{3}$ versus more labile oxides and reflects the relative amount of feldspars and clay minerals in a sample. The CIA averages 50 for unaltered albite, anorthite, and potassic feldspar, and measures $30-40$ for basalt, $45-55$ for granites and granodiorites, $75-85$ for illite, 75 for muscovite, and close to 100 for kaolinite and chlorite (Nesbitt and Young, 1982).

The CIA index has been used previously to estimate the climatic control on chemical changes in various types of environments, including lacustrine sediments, and in environments of different ages (e.g., Roman-Ross et al., 2002; Das and Haake, 2003; Roy et al., 2010). However, the CIA does not exclusively reflect the climatic conditions that occurred in the catchment during weathering. The index can also be influenced by post-depositional modifications of clay minerals, such as diagenetic illitization of smectite, which complicates estimates of the extent of alteration (Xiao et al., 2010).

In the sediment sequence of Lake El'gygytgyn, the CIA ranges from 59.91 to 76.16 (mean 65.84) during warm intervals and between 62.69 and 75.15 (mean 69.40) during cold stages (Fig. 5). Volcanic rocks from the El'gygytgyn area, in contrast, exhibit a CIA of 43.70-56.32 (mean 49.71).

Trends in silicate weathering can be inferred from the $\mathrm{Al}_{2} \mathrm{O}_{3}-\left(\mathrm{CaO}+\mathrm{Na}_{2} \mathrm{O}\right)-\mathrm{K}_{2} \mathrm{O}$ ternary diagram (Nesbitt and Yang, 1984). For the El'gygytgyn sediments, an obvious trend line parallels the $\mathrm{Al}_{2} \mathrm{O}_{3}-\left(\mathrm{CaO}+\mathrm{Na}_{2} \mathrm{O}\right)$ boundary and indicates a progressive depletion of $\mathrm{Ca}$ and $\mathrm{Na}$ during weathering in preference to $\mathrm{K}$. Values for the volcanic rocks plot close to the plagioclase K-feldspar join line (Fig. 8a), indicating that feldspars are the dominant Al-bearing minerals. In contrast, samples of pebbles collected from the El'gygytgyn beach fall slightly above the plagioclase K-feldspar line, indicating a rather low degree of chemical weathering. Sediments from cold and warm stages show an intermediate intensity of alteration with higher values exhibited during the cold intervals (Fig. 8a). In general, the sediment data plots below the smectite-illite line with the lower position of data of warm stage sediments, suggesting that sediments of warm stages contain more feldspar. Enhanced concentrations of feldspar in the surface sediments of Lake El'gygytgyn are linked to their high coarse silt and sand contents (Wennrich et al., 2013a).

\subsubsection{Plagioclase index of alteration}

The plagioclase index of alteration (PIA) estimates the weathering intensity of plagioclase (Fedo et al., 1995) and is calculated according to the following equation: 
$\left[\left(\mathrm{Al}_{2} \mathrm{O}_{3}-\mathrm{K}_{2} \mathrm{O}\right) /\left(\mathrm{Al}_{2} \mathrm{O}_{3}+\mathrm{CaO}+\mathrm{Na}_{2} \mathrm{O} \mathrm{K} \mathrm{K}_{2} \mathrm{O}\right)\right] \times 100 .(2)$

The PIA in the Lake El'gygytgyn record varies from 63.81 to 86.35 (mean 71.80) in interglacial sediments and from 67.44 to 84.92 (mean 75.95) in glacial-age samples. Volcanic rocks collected in the lake catchment exhibit much lower PIA values (range 43.02 to 59.79 ; mean 49.99 ). The PIA of the pelagic sediments shows a strong positive correlation with other weathering indices (Table 2).

As shown in the ternary diagram $\mathrm{CaO}-\left(\mathrm{Al}_{2} \mathrm{O}_{3}-\right.$ $\mathrm{K}_{2} \mathrm{O}$ ) $-\mathrm{Na}_{2} \mathrm{O}$ (Fig. 8b), PIA values from sediment data and the Pykarvaam and Ergyvaam formations, the dominant rock type in the lake catchment, are located in the central part of the diagram, although displaying a slight shift to an albite composition. The position of the glacial sediments closer to the $\mathrm{Al}_{2} \mathrm{O}_{3}-\mathrm{K}_{2} \mathrm{O}$ apex of the diagram suggests a higher degree of alteration as compared to the interglacial deposits (Fig. 8b).

\subsubsection{Chemical index of weathering}

The chemical index of weathering (CIW) was proposed by Harnois (1988) and is calculated using the equation

$\mathrm{CIW}=\left[\mathrm{Al}_{2} \mathrm{O}_{3} /\left(\mathrm{Al}_{2} \mathrm{O}_{3}+\mathrm{CaO}+\mathrm{NaO}\right)\right] \times 100$,

with $\mathrm{Al}_{2} \mathrm{O}_{3}$ treated as an immobile component and $\mathrm{CaO}$ and $\mathrm{Na}_{2} \mathrm{O}$ used as mobile elements. $\mathrm{K}$, in contrast, is not included in this index, because it may be leached and/or accumulated in the residual weathering products. Fedo et al. (1995) point out that $\mathrm{Al}$ in this index is used without any correction for its inclusion in K-feldspar, and therefore K-feldsparrich rocks yield very high CIW values. Potassic granite, for example, has a CIW of 80 and fresh K-feldspar has an index of 100 , values that are similar to residual products of chemical weathering (smectite: 80; kaolinite, illite, and gibbsite: 100; Fedo et al. 1995).

The CIW ranges from 69.03 to 88.58 (72.28 on average) during interglacials and increases to 72.39 to 87.43 (mean 79.42) during glacial periods due to the depletion of $\mathrm{Na}$ and $\mathrm{Ca}$ relative to $\mathrm{Al}$. In unweathered volcanic rocks from the El'gygytgyn area, the index varies from 45.94 to 68.47 (mean 56.17).

\subsection{Geochemical indices as proxy for environmental changes}

Geochemical indices commonly differ between glacial and interglacial intervals, suggesting that conditions in cold and warm periods exerted distinct influences on the sedimentary record. For example, glacial sediments show high values of CIA, CIW, Rb/Sr, Ba/Sr, LOI depleted by potassium, sodium, calcium, and strontium. Thus, these characteristics should be helpful in differentiating glacials and interglacials in the El'gygytgyn record.
Chemical weathering generally is considered to increase in warm and wet climates, although this process can also be active under cold climatic conditions (e.g., Darmody et al., 2000; Hall et al., 2002). Nonetheless, temperature and precipitation have been shown to be strong controls on the rates of chemical weathering (e.g., White and Blum, 1995).

Surprisingly, sediments from the super interglacial MIS 11.3 exhibit low weathering indices as compared to glacial sediments. Furthermore, weathering indices for MIS 11.3 are lower than Holocene values, even though the super interglacial was considerably warmer and wetter than the Holocene. That is, maximum summer temperature and annual precipitation of $\sim 4$ to $5^{\circ} \mathrm{C}$ and $\sim 300 \mathrm{~mm}$, respectively, were reconstructed for MIS 11.3, whereas the mean temperature of the warmest month and mean annual precipitation during the Holocene thermal optimum were only $\sim 1$ to $2{ }^{\circ} \mathrm{C}$ and $\sim 50 \mathrm{~mm}$ higher than today (Melles et al., 2012). Hence, a simple application of chemical indices for inferring chemical weathering intensity within the El'gygytgyn catchment will be incorrect. Below we discuss and evaluate four scenarios that might account for the differences between chemical indices observed in the glacial and interglacial sediments from Lake El'gygytgyn.

1. Grain size is considered an important factor that can influence the expected relationship between sediment composition and geochemical indices (e.g., Von Eynatten et al., 2012). In the El'gygytgyn sediments, sand content does not exceed $15.5 \%$, and the average silt and clay contents are ca. 69.2 and $27.7 \%$, respectively. Mean grain size varies between 2.5 and $9.3 \mu \mathrm{m}$ and is higher in interglacial sediments (Francke et al., 2013). Geochemical data from volcanic rocks and sediments show a strong dependence of geochemical indices and granulometry. Volcanic rocks and impactites display the lowest values of CIA, PIA, and CIW. In finer sediments, the values of geochemical indices increase (Fig. 9). To further investigate the dependence of geochemical data and grain size in the El'gygytgyn record, one sample from MIS 7 was separated into two size fractions ( $<40$ and $>40 \mu \mathrm{m})$. The $<40 \mu \mathrm{m}$ fraction ( $90 \%$ of the total sample weight) is depleted in $\mathrm{CaO}, \mathrm{Na}_{2} \mathrm{O}$, and $\mathrm{K}_{2} \mathrm{O}$ and displays higher CIA (64.58), PIA (70.18) and CIW (74.97) indices as compared to the coarser size fraction. The values of CIA, PIA and CIW for the $>40 \mu \mathrm{m}$ fraction $(10 \%$ of the sample weight) are $57.15,60.21$, and 67.22 , respectively. Cold and warm periods experienced different sedimentological regimes. A perennial ice cover on the lake during peak glacial times restricted the transport of coarse-grained, less-altered sediments to the basin. However, this situation enabled finer particles to be transported to the center of the lake through cracks in the ice or through the formation of moats around the shore during summer (Asikainen et al., 


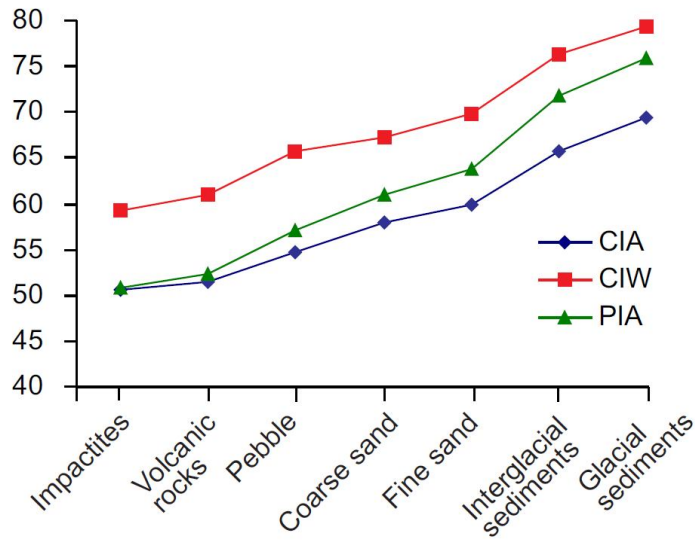

Fig. 9. Geochemical indices (CIA, PIA, CIW) from impactites $(n=9)$, volcanic rocks $(n=19)$ (Bely and Belaya, 1998), pebbles comprised of volcanic rocks $(n=11)$ (Feldman et al., 1980), coarse sand $(n=2)$, fine sand $(n=1)$, interglacial sediments $(n=228)$, and glacial sediments $(n=387)$.

2007). During interglacials, the greater precipitation would have increased the transport energy of streams draining into the lake that in turn would carry coarser clastic material to the basin. Additionally, the longer ice-free period combined with wind-induced lake currents would result in a greater redistribution of clastic material within the basin (Francke et al., 2013). Asikainen et al. (2007) noted that chlorite is the typical clay mineral in glacial sediments, whereas smectite and illite are more abundant during interglacials. An abundance of chlorite would increase certain geochemical indices; for example, the CIA and CIW for chlorite is 100 (Nesbitt and Young, 1982; Fedo et al., 1995).

2. Variations in the sediment geochemistry between glacial and interglacial periods can be caused by changes in sediment provenance. However, this explanation can be excluded in the case of Lake El'gygytgyn, because it is a closed basin with a very restricted watershed that is bordered by a distinct crater rim (Fig. 1). The highly altered material found in the El'gygytgyn record possibly was transported by eolian processes, originating in remote regions. Fedorov et al. (2013) showed that streams are the major agents for carrying clastic materials to the basin during spring and summer under modern climate conditions. Total eolian supply amounts to only $4-5 \%$ of the total sediment input. Prevailing local winds on the lake are from the north and south. They are strong and persistent, and this likely plays an important role in controlling the lake shape (Nolan and Brigham-Grette, 2007). Past wind direction was likely the same. Today large areas of eolian sediment are absent in the El'gygytgyn catchment and in areas immediately to the north and south of the lake. In other regions of Chukotka and in Yakutia, silt-dominated Pleistocene sediments are widespread. They are associated with ice-rich permafrost and are referred to as ice-complex or yedoma deposits. There are different explanations for the origin of the ice-complex sediments, including an eolian genesis (Tomirdiaro and Chernen'ky, 1987). Geochemical data of the ice complex are available from the Anadyr River to the south of the lake and along the Arctic lowlands to the north (Tomirdiaro, 1972; Tomirdiaro and Chernen'ky, 1987). As part of our analysis, we compared the geochemical data from the predominant volcanic rocks and pebbles and from lake and ice-complex sediments. On the ternary $\mathrm{Al}_{2} \mathrm{O}_{3}-\left(\mathrm{CaO}+\mathrm{Na}_{2} \mathrm{O}\right)-\mathrm{K}_{2} \mathrm{O}$ and $\mathrm{CaO}-\left(\mathrm{Al}_{2} \mathrm{O}_{3}-\mathrm{K}_{2} \mathrm{O}\right)-\mathrm{Na}_{2} \mathrm{O}$ diagrams (Fig. 8), the various El'gygytgyn data plot parallel to the $\left(\mathrm{CaO}+\mathrm{Na}_{2} \mathrm{O}\right)-\mathrm{Al}_{2} \mathrm{O}_{3}$ and $\mathrm{Na}_{2} \mathrm{O}-\left(\mathrm{Al}_{2} \mathrm{O}_{3}-\mathrm{K}_{2} \mathrm{O}\right)$ axes, respectively, clearly indicating local volcanic rocks to be the major source of clastic material deposited on the lake floor. In contrast, the ice-complex data form a separate group on the diagrams. These results suggest that any eolian input into the lake during glacial intervals must have been derived from the product of local weathering products of the volcanic rocks. This scenario is unlikely.

3. During the warm and wet interglacials, the chemical weathering was increased and as a result the surface waters were enriched in mobile elements, such as $\mathrm{Ca}, \mathrm{Na}, \mathrm{K}$, and $\mathrm{Sr}$. The consequent increase in stream and overland water flow into the lake resulted in a higher total content of these elements in the lake sediments. In this case, low values of CIA, PIA, CIW, and $\mathrm{Rb} / \mathrm{Sr}$ reflect the high degree of chemical weathering. A similar scenario has been suggested for the Heqing paleolake basin (An et al., 2011), Daihai Lake (Jin et al., 2001), and Barkol Lake (Zhong et al., 2012). However Lake El'gygytgyn is extremely oligotrophic, meaning that the water is low in anions and cations $\left(<1 \mathrm{mg} \mathrm{L}^{-1}\right)$ and has a low conductivity based on measurements carried out in May (prior to snowmelt) and in August (following snow and ice melt) at Lake El'gygytgyn (Cremer and van de Vijver, 2006). Therefore, dissolved $\mathrm{Ca}^{2+}, \mathrm{Na}^{+}$, and $\mathrm{K}^{+}$contributed only slightly to the total contents of these elements in the sediments. In contrast, at Barkol Lake the water content of $\mathrm{Ca}, \mathrm{Na}$, and $\mathrm{K}$ was $-444.8,-62089.39$, and $-1117.35 \mathrm{mg} \mathrm{L}^{-1}$, respectively (Zhong et al., 2012). Thus, this scenario is also unlikely to explain the El'gygytgyn patterns.

4. Diagenetic processes can obscure the detrital geochemical signals. Glacial facies at Lake El'gygytgyn supposedly accumulated under anoxic bottom-water conditions (Melles et al., 2007, 2012), resulting in the 


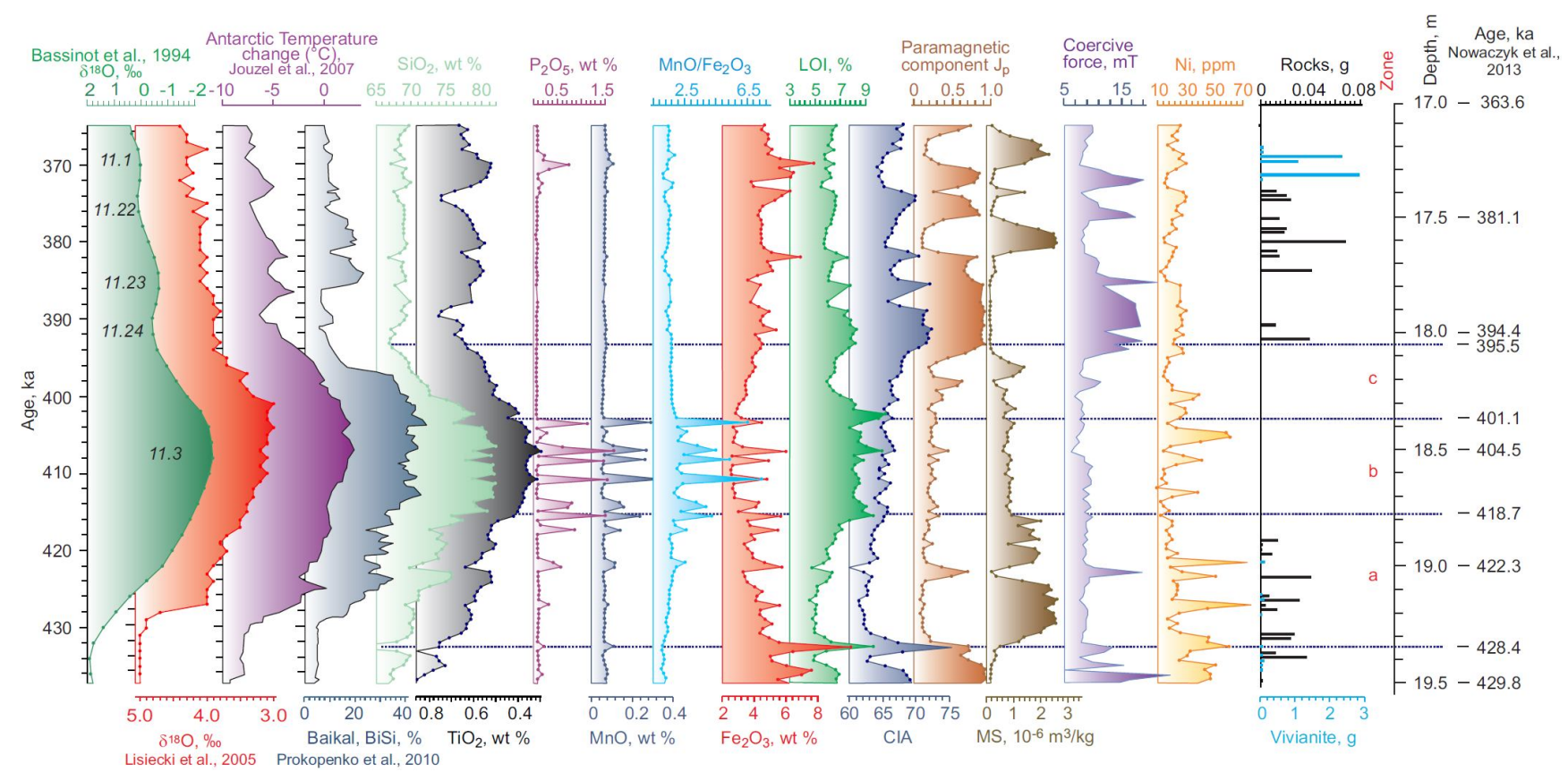

Fig. 10. Geochemical structure of MIS 11. Note that $\mathrm{TiO}_{2}$ is plotted using a reversed scale.

dissolution of magnetic minerals (Nowaczyk et al., 2007). The formation of authigenic vivianite, $\mathrm{Fe}-\mathrm{Mn}$ aggregates, pyrite, and greigite indicates a strong postdepositional alteration of sediments during anoxia. This process can also lead to the partial dissolution of silicates, which is accompanied by a loss of cations as was reported for Sea of Okhotsk sediments (Wallmann et al., 2008). A similiar cation depletion in anoxic glacial sediments might explain the high indices of CIA, CIW, and PIA. However, additional mineralogical investigations are required to confirm such a scenario.

In summary, our data indicate that geochemical indices and selected elemental ratios mirror sedimentation conditions and, possibly, diagenetic processes that are triggered by environmental and climate changes during glacials and interglacials.

\section{Geochemical zonation}

Down-core changes in major and trace elements and in elemental ratios display a strong geochemical zonation that corresponds to marine isotopic stages (Figs. 4 and 6). The samples analyzed in this study represent a wide range of climate conditions, varying from the climatic optima of MIS 11 and MIS 9 to the frigid glacial environments of MIS 6, MIS 8, and MIS 10 (Lozhkin and Anderson, 2013; Lozhkin et al., 2013). Vegetation types present during MIS 11 indicate greater summer warmth and annual precipitation as compared to modern
(Lozhkin and Anderson, 2013; Melles et al., 2012, Tarasov et al., 2013). Pollen-based reconstructions of mean temperatures for July and January were +12 to $16^{\circ} \mathrm{N}$ and -20 to $-24^{\circ} \mathrm{N}$, respectively, and mean annual precipitation was $\sim 550$ to $600 \mathrm{~mm}$. The following interglacials and interstadials were cooler in comparison to MIS 11, and sediment data show a decreasing trend in $\mathrm{SiO}_{2}$. Mean summer temperatures during MIS 9.3 ranged from +12 to $14^{\circ} \mathrm{C}$ (Lozhkin et al., 2013). Simultaneously, sediments of MIS 9.3 contain less $\mathrm{SiO}_{2}$ as compared to MIS 11 (Fig. 4). During MIS 7 mean July temperature was $+2.4{ }^{\circ} \mathrm{C}$ (Matrosova, 2009), and the warm substages of MIS 7 display low concentrations of $\mathrm{SiO}_{2}$. During glacial intervals, mean July and January temperatures were +2 to $3{ }^{\circ} \mathrm{C}$ and -24 to $-25^{\circ} \mathrm{C}$, respectively (Matrosova, 2009). Glacial sediments are characterized by the highest content of $\mathrm{TiO}_{2}, \mathrm{Fe}_{2} \mathrm{O}_{3}$, and $\mathrm{MgO}$ and by the lowest values of $\mathrm{SiO}_{2}$ (Fig. 4). Below we give a detailed description of MIS 11 and MIS 7.4 sediments, which represent the warmest and coldest stages within the core interval reported here.

\subsection{Geochemical structure of MIS 11}

MIS 11 is known to be the warmest and longest interglacial interval of the past $500 \mathrm{ka}$ (e.g., Howard, 1997) and has been subdivided into several substages: 11.1, 11.22, 11.23, 11.24, and 11.3 (Bassinot et al., 1994). On the basis of the El'gygytgyn geochemical data, however, substage 11.3 can be further divided into three zones (Fig. 10), each representing different sedimentation conditions. The lower zone (zone a; 428.4-418.7 ka) is transitional between MIS 12 
and MIS 11 and marks the initial warming. This zone is characterized by gradual increases in $\mathrm{SiO}_{2}, \mathrm{Na}_{2} \mathrm{O}, \mathrm{K}_{2} \mathrm{O}$, $\mathrm{CaO}$, and $\mathrm{Sr}$, and decreases in $\mathrm{TiO}_{2}, \mathrm{Al}_{2} \mathrm{O}_{3}, \mathrm{MgO}, \mathrm{Fe}_{2} \mathrm{O}_{3}$, LOI, CIA, and CIW, as characteristic of all warm stages. At this time, the lake had a semipermanent ice cover, lake waters were mixed, and more coarse material was supplied to the center of the basin. In the earliest stages of warming, anoxic conditions probably still existed on the lake bottom, resulting in favorable circumstances for the formation of large vivianite nodules (Fig. 10). During the spring, the lake supported a thick ice cover, but active snowmelt caused a significant amount of debris to be carried by streams and deposited onto the surface of the ice (Fedorov et al., 2013). As visible in large amounts of rock fragments (Fig. 10), coarse-grained sand and gravel are supposed to be delivered to the center part of the lake by ice floes. Zone a is characterized by a distinct peak in the geochemical data. These curves resemble both the distribution of biogenic silica in Lake Baikal (Prokopenko et al., 2006, 2010) and the temperature reconstructions derived from Antarctic ice cores marked as event 11.33 (Spahni et al., 2005; Jouzel et al., 2007). The similarity in trends from such distant sites argues for the influence of global forcings on these records.

The middle zone (zone b; 418.7-401.1 ka) of substage 11.3 exhibits a sharp increase in $\mathrm{SiO}_{2}$ owing to a pronounced BSi maximum (Melles et al., 2012). This increase represents high bioproductivity during the sediment deposition. A simultaneous drop to minimum values in $\mathrm{TiO}_{2}$, $\mathrm{Al}_{2} \mathrm{O}_{3}$, and $\mathrm{MgO}$, and lesser but significant decreases in $\mathrm{Na}_{2} \mathrm{O}, \mathrm{CaO}, \mathrm{K}_{2} \mathrm{O}, \mathrm{Rb}, \mathrm{Sr}, \mathrm{Zr}$, and $\mathrm{Ba}$, can presumably be traced to dilution by high amounts of biogenic silica. On the other hand, values of LOI markedly increase during zone b, an increase that is common during glacial intervals. High LOI reflects enhanced primary production and incomplete decomposition of organic matter in the oxygenated bottom water. A few peaks in $\mathrm{Cr}$ and $\mathrm{Ni}$ occur in this zone. However, they do not coincide with those of other elements, and further detailed mineralogical investigations are needed to explain this pattern.

Our data indicate that during zone $b$, the warmest period of substage 11.3, sedimentation conditions in the lake varied. The sharp parallel variations in $\mathrm{P}_{2} \mathrm{O}_{5}, \mathrm{MnO}$, and $\mathrm{Fe}_{2} \mathrm{O}_{3}$ in zone $\mathrm{b}$ are underscored by high correlation coefficients of $0.93,0.86$, and 0.94 for $\mathrm{P}_{2} \mathrm{O}_{5} / \mathrm{MnO}, \mathrm{Fe}_{2} \mathrm{O}_{3} / \mathrm{MnO}$, and $\mathrm{Fe}_{2} \mathrm{O}_{3} / \mathrm{P}_{2} \mathrm{O}_{5}$, respectively. These elements are typically contained in fine-grained vivianite, whose presence in the El'gygytgyn samples was verified by examination of smear slides. In contrast to glacial sediments, vivianite nodules $>0.25 \mathrm{~mm}$ do not occur in zone $b$. The curve of high $\mathrm{SiO}_{2}$ exhibits a saw-toothed pattern and is out of phase with the $\mathrm{P}_{2} \mathrm{O}_{5}, \mathrm{MnO}$, and $\mathrm{Fe}_{2} \mathrm{O}_{3}$ curves (Fig. 10). This relationship is clearly shown by a highly negative correlation coefficient of -0.50 between $\mathrm{SiO}_{2}$ and $\mathrm{Fe}_{2} \mathrm{O}_{3}$ (Table 1). Furthermore, numerous peaks in $\mathrm{Fe}_{2} \mathrm{O}_{3}$ and corresponding maxima in the $\mathrm{MnO} / \mathrm{Fe}_{2} \mathrm{O}_{3}$ ratio indicate that these levels are associated with reducing environments. These data suggest that the laminations observed in the MIS 11.3 sediments were formed by alternating layers of (1) biogenic sediments greatly enriched in $\mathrm{SiO}_{2}$ that were deposited on the lake bottom under oxidizing conditions; and (2) sediments that were less enriched in $\mathrm{SiO}_{2}$ but still contained abundant $\mathrm{Fe}$, $\mathrm{P}$, and $\mathrm{Mn}$, which probably formed under anoxic conditions. Even in the oxidized horizons, MS is low, presumably because of the dilution of magnetic minerals by BSi. However, in contrast to the low MS minima in anoxic glacial sediments, the low paramagnetic component of magnetization indicates that the dissolution of magnetic minerals was negligible. Zone b lacks a coarse-grained component (e.g., sand or gravel), which implies that only minor ice-floe activity occurred at that time.

The alternation of oxic and anoxic horizons suggests that when anoxic conditions occurred at the water-sediment interface, bioproductivity was high. This increase probably reflects the presence of favorable, highly oxygenated conditions in the middle and upper parts of the water column and increased decomposition of organic matter on the lake bottom.

The uppermost zone of substage 11.3 (zone c; 401.1$395.5 \mathrm{ka}$ ) represents decreasing biological productivity. It is also characterized by a gradual decrease in $\mathrm{SiO}_{2}$ and LOI, and a simultaneous increase in $\mathrm{TiO}_{2}, \mathrm{MgO}, \mathrm{Fe}_{2} \mathrm{O}_{3}, \mathrm{Al}_{2} \mathrm{O}_{3}$ and other elements. Furthermore, there is an absence of $\mathrm{P}_{2} \mathrm{O}_{5}$ and $\mathrm{MnO}$ peaks, vivianite nodules, and coarse sediments. Finer-grained sediments progressively increase upcore, but the record does not display any sharp changes in sedimentation.

In the upper part of MIS 11 (depth 18.07-17.11 m), the accumulation of biogenic silica was insignificant, although sedimentation conditions were variable. The $\mathrm{SiO}_{2}$ content ranges between 66.92 and $69.97 \%$ (mean $68.65 \%$ ) and exhibits only minor fluctuations. However, the $\mathrm{TiO}_{2}$ curve displays four distinct minima at depths of $17.87(392.1 \mathrm{ka})$, $17.73(389.1 \mathrm{ka}), 17.61$ (385.7 ka), and 17.29 (373.4 ka) m. These depths correspond to peak values in CIA, PIA, and CIW. The common occurrence of coarse sand and gravel in substage 11.2 might indicate enhanced ice-floe activity.

\subsection{Geochemical structure of MIS 6.6 and 7.4}

Among the glacial substages, MIS 7.4 and MIS 6.6 are the most pronounced (Figs. 4 and 6) and show similar geochemical features. As seen in the element distributions for MIS 7.4 (Fig. 11), these full glacial sediments are characterized by the lowest $\mathrm{SiO}_{2}$, suggesting that a biogenic contribution to the sediment was low or lacking. Synchronously, $\mathrm{TiO}_{2}, \mathrm{Fe}_{2} \mathrm{O}_{3}$, $\mathrm{MgO}, \mathrm{Al}_{2} \mathrm{O}_{3}$ and $\mathrm{Zr}$ are extremely enriched. There are few specific similarities in the geochemical behavior of MIS 7.4 and MIS 6.6 as compared to other glacial intervals. Nearly all geochemical characteristics, including element contents, 


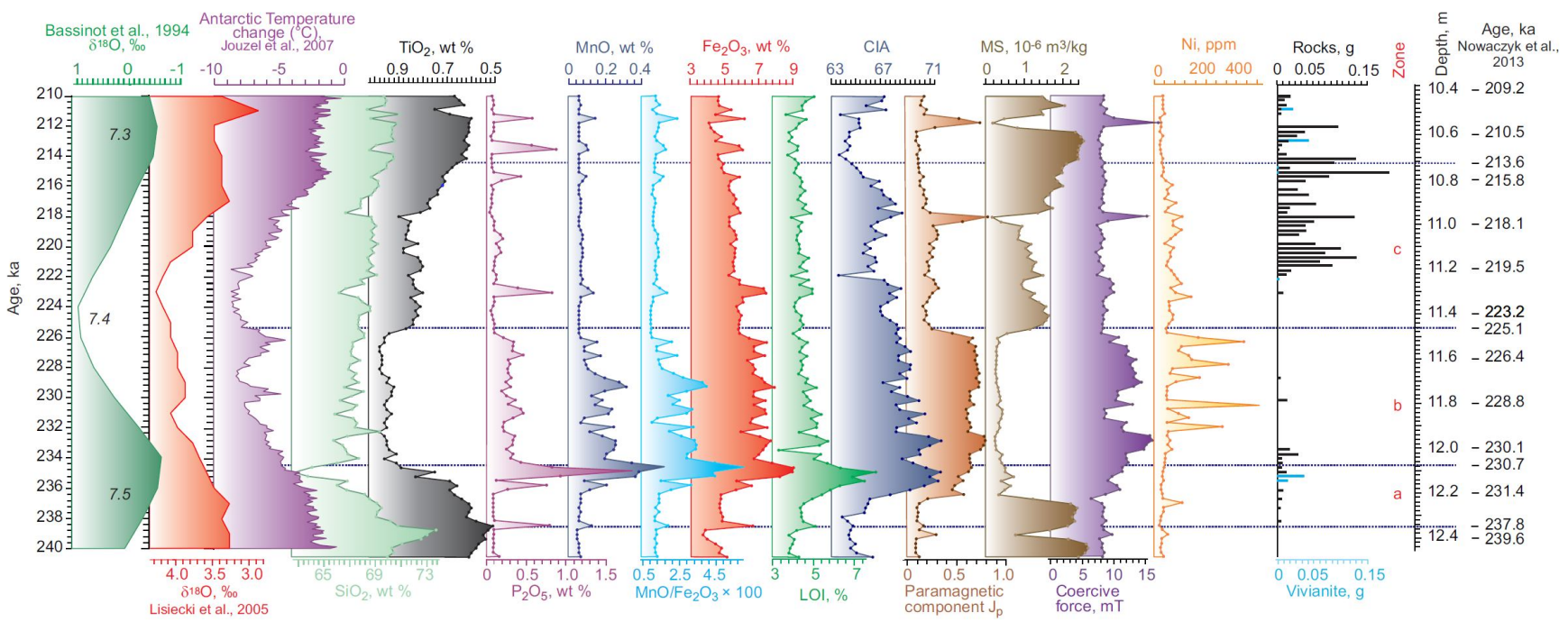

Fig. 11. Geochemical structure of MIS 7.4. Note that $\mathrm{TiO}_{2}$ is plotted using a reversed scale.

indices, and ratios, simultaneously reflect the impact of climate change. $\mathrm{TiO}_{2}$ increases gradually to a maximum.

The lower parts of these substages, marked as zone a (237.8-230.7 ka) (Fig. 11), are characterized by a sharp decrease in $\mathrm{SiO}_{2}$, suggesting a lessening in biogenic accumulation. High peaks in $\mathrm{Fe}_{2} \mathrm{O}_{3}, \mathrm{P}_{2} \mathrm{O}_{5}, \mathrm{MnO}, \mathrm{Mn} / \mathrm{Fe}_{2} \mathrm{O}_{3}$, and LOI are indicative of reducing conditions in the bottom waters and at the sediment-water interface. They are accompanied by the precipitation of Fe-bearing minerals, such as vivianite and/or Fe-Mn aggregates. The lack of large vivianite nodules in these intervals suggests a direct precipitation of finegrained vivianite from the lake water, presumably triggered by climatic and/or environmental deterioration. Low MS and high $J_{\mathrm{p}}$ values in the upper part of zone a indicate that the dissolution of magnetic minerals occurred during these substages. In contrast, the lack of correlation between $J_{\mathrm{p}}$ and phosphorus and manganese suggests phyllosilicates as the most likely primary contributors of paramagnetic minerals in the sediments. A high abundance of coarse-grained sand in the generally fine-grained sediments implies intensified icefloe activity.

The middle part of substage 7.4 (zone b, 230.7-225.1 ka) and the lower part of substage 6.6 (not shown) are enriched in $\mathrm{Ni}$ and $\mathrm{Cr}$ and show high LOI. Concentrations of $\mathrm{K}_{2} \mathrm{O}$, $\mathrm{CaO}, \mathrm{Na}_{2} \mathrm{O}, \mathrm{Sr}, \mathrm{Rb}$, and $\mathrm{Ba}$ are low but remain higher than during MIS 11. The zone $b$ sediment does not contain any coarse material, suggesting a permanent ice cover on the lake with only narrow moats in summer. Such a configuration would restrict ice movement and thus the transport of coarse-grained material to the lake center.

Abundant coarse material again occurs in zone c (225.1$213.6 \mathrm{ka}$ ). Geochemically, the sediments of this zone represent an intermediate state between glacials and interglacials.

\section{Conclusions}

The inorganic geochemistry of Lake El'gygytgyn sediments indicates distinct down-core variations in elemental composition over the past ca. 125-430 ka. The correspondence of these variations to glacial and interglacial periods is based on complementary biological and geochemical indicators. Interglacial sediments show high content of $\mathrm{SiO}_{2}, \mathrm{Na}_{2} \mathrm{O}$, $\mathrm{CaO}, \mathrm{K}_{2} \mathrm{O}$, and $\mathrm{Sr}$ but low values for $\mathrm{Al}_{2} \mathrm{O}_{3}, \mathrm{Fe}_{2} \mathrm{O}_{3}, \mathrm{TiO}_{2}$, and $\mathrm{MgO}$. Glacial sediments, in contrast, exhibit opposite trends. Peaks in $\mathrm{P}_{2} \mathrm{O}_{5}$ and $\mathrm{MnO}$ coincide with an increased abundance of fine-grained vivianite, which indicates times of dominating reducing conditions in the sediment and/or bottom waters. Super interglacial stages 9.3 and 11.3 are enriched in $\mathrm{SiO}_{2}$ due to the increased flux of biogenic silica, a reflection of maximum diatom production. The geochemical structure of MIS 11 shows very similar characteristics that have been documented in similar-age records from Lake Baikal and Antarctica. Among the glacial substages, MIS 7.4 and MIS 6.6 are the most marked. They are characterized by the lowest $\mathrm{SiO}_{2}$ values, suggesting low or absent diatom productivity, and very high $\mathrm{TiO}_{2}, \mathrm{Fe}_{2} \mathrm{O}_{3}, \mathrm{MgO}, \mathrm{Al}_{2} \mathrm{O}_{3}$ and $\mathrm{Zr}$. Peaks in $\mathrm{Fe}_{2} \mathrm{O}_{3}$ coincide with high $\mathrm{MnO} / \mathrm{Fe}_{2} \mathrm{O}_{3}$ ratios, indicating a reducing condition in the sediments and/or bottom water.

Geochemical indices and some elemental ratios indicate a higher alteration of glacial sediments as compared to interglacial sediments accompanied by a depletion of mobile elements, such as $\mathrm{Na}, \mathrm{Ca}, \mathrm{K}$, and $\mathrm{Sr}$. This alteration might be caused by the sedimentation regime and/or post-depositional diagenetic processes. 
Acknowledgements. Drilling operations were funded by the ICDP, the NSF, the German Federal Ministry of Education and Research (BMBF), the Alfred Wegener Institute and the Helmholtz Centre Potsdam (GFZ), the Far East Branch of the Russian Academy of Sciences (FEB RAS), the Russian Foundation for Basic Research (RFBR), and the Austrian Federal Ministry of Science and Research. The Russian Global Lake Drilling 800 drilling system was developed and operated by DOSECC. Funding of sample analyses was provided by the Civilian Research and Development Foundation (grant RUG1-2987-MA-10), RFBR (12-05-00286, 14-05-00573), and FEB RAS (12-II-SB-08-024, 12-III-A-08-191). We gratefully acknowledge Patricia Anderson for the correction of our English that substantially improved this paper.

Edited by: J. Brigham-Grette

\section{References}

An, Z., Clemens, S. C., Shen, J., Qiang, X., Jin, Z., Sun, Y. W. L., Luo, J., Wang, S., Xu, H., Cai, Y., Zhou, W., Liu, X., Liu, W., Shi, Z., Yan, L., Xiao, X., Chang, H., Wu, F., Ai, L., and Lu, F.: Glacial-Interglacial Indian Summer Monsoon Dynamics, Science, 333, 719-723, 2011.

Asikainen, C. A., Francus, P., and Brigham-Grette, J.: Sedimentology, clay mineralogy and grain-size as indicators of $65 \mathrm{ka}$ of climate change from El'gygytgyn Crater lake, Northeastern Siberia, J. Paleolimnol., 37, 105-122, 2007.

Bassinot, F. C., Labeyrie, L. D., Vincent, E., Quidelleur, X., Shackleton, N. J., and Lancelot, Y.: The astronomical theory of climate and the age of the Brunhes-Matuyama magnetic reversal, Earth Planet. Sc. Lett., 126, 91-108, 1994.

Bely, V. F. and Belaya, B. V.: Late stage of the OCVB development (upstream of the Enmyvaam River), NEISRI FEB RAS Press, Magadan, 1998.

Bely, V. F. and Raikevich, M. I.: The El'gygytgyn lake basin (geological structure, morphostructure, impactites, problems of investigation and preservation of nature), NEISRI FEB RAS Press, Magadan, 1994.

Bokhorst, M. P., Beets, C. J., Markovic, S. B., Gerasimenko, N. P., Matviishina, Z. N., and Frechen, M.: Pedo-chemical climate proxies in Late Pleistocene Serbiane-Ukrainian loess sequences, Quatern. Int., 198, 113-123, 2009.

Borkhodoev, V. Ya.: Accuracy of the fundamental parameter method for X-ray fluorescence analysis of rocks, X-Ray Spectrom., 31, 209-218, 2002.

Borkhodoev, V. Ya.: X-ray fluorescence determination of rubidium, strontium, yttrium, zirconium and niobium in rocks, J. Trace Microprobe T., 16, 341-352, 1998.

Boyle, J. F.: Inorganic geochemical methods in paleolimnology, in: Tracking Environmental Change Using Lake Sediments: Physical and Geochemical Methods, edited by: Last, W. M. and Smol, J. P., Springer, Berlin, 83-141, 2002.

Brigham-Grette, J., Melles, M., Minyuk, P., Andreev, A., Tarasov, P., DeConto, R., Koenig, S., Nowaczyk, N., Wennrich, V., Rosén, P., Haltia-Hovi, E., Cook, T., Gebhardt, C., Meyer-Jacob, C., Snyder, J., and Herzschuh, U.: Pliocene Warmth, extreme Polar Amplification, and Stepped Pleistocene Cooling recorded in NE Russia, Science, 340, 1421-1427, 2013.
Brown, E. T., Johnson, T. C., Scholz, C., Cohen, A. S., and King, J. W.: Abrupt change in tropical African climate linked to the bipolar seesaw over the past 55,000 years, Geophys. Res. Lett., 34, L20702, doi:10.1029/2007GL031240, 2007.

Burov, B. V., Nourgaliev, D. K., and Yasonov, P. G.: Paleomagnetic analysis, KGU Press, Kazan, 1986.

Cremer, H. and van de Vijver, B.: On Pliocaenicus costatus (Bacillariophyceae) in Lake El'gygytgyn, East Siberia, Eur. J. Phycol., 41, 169-178, 2006.

Cremer, H. and Wagner, B.: The diatom flora in the ultraoligotrophic Lake EI'gygytgyn, Chukotka, Polar Biol., 26, 105114, doi:10.1007/s00300-002-0445-0, 2003.

Cunningham, L., Vogel, H., Wennrich, V., Juschus, O., Nowaczyk, N., and Rosén, P.: Amplified bioproductivity during Transition IV (332000-342000 yr ago): evidence from the geochemical record of Lake El'gygytgyn, Clim. Past, 9, 679-686, doi:10.5194/cp-9-679-2013, 2013.

Darmody, R. G., Thorn, C. E., Harder, R. L., Schlyter, J. P. L., and Dixon, J. C.: Weathering implications of water chemistry in an arctic-alpine environment, northern Sweden, Geomorphology, 34, 89-100, 2000.

Das, B. K. and Haake, B.-G.: Geochemistry of Rewalsar Lake sediment, Lesser Himalaya, India; implications for source-area weathering, provenance and tectonic setting, Geosci. J., 7, 299 312, 2003.

Dasch, E. J.: Strontium isotopes in weathering profiles, deep-sea sediments and sedimentary rocks, Ceochim. Cosmochim. Acta, 33, 1521-1552, 1969.

Davison, W.: Iron and manganese in lakes, Earth Sci. Rev., 34, 119 163, 1993.

Duzgoren-Aydin, N. S., Aydin, A., and Malpas, J.: Re-assessment of chemical weathering indices: case study on pyroclastic rocks of Hong Kong, Eng. Geol., 63, 99-119, 2002.

Fagel, N., Alleman, L. Y., Granina, L., Hatert, F., Thamo-Bozso, E., Cloots, R., and Andre, L.: Vivianite formation and distribution in Lake Baikal sediments, Global Planet. Change, 46, 315-336, 2005.

Fedo, C. M., Nesbitt, H. W., and Young, G. M.: Unraveling the effects of potassium metasomatism in sedimentary rocks and paleosols, with implications for paleoweathering conditions and provenance, Geology, 23, 921-924, 1995.

Fedorov, G., Nolan, M., Brigham-Grette, J., Bolshiyanov, D., Schwamborn, G., and Juschus, O.: Preliminary estimation of Lake El'gygytgyn water balance and sediment income, Clim. Past, 9, 1455-1465, doi:10.5194/cp-9-1455-2013, 2013.

Feldman, V. I., Granovskyi, L. B., Naumova, I. G., and Nikishina, N. N.: Some peculiarities of chemical composition of impactites from the El'gygytgyn meteoritic crater (Chukotka), Meteoritika, 39, 110-113, 1980.

Fralick, P. W. and Kronberg, B. I.: Geochemical discrimination of elastic sedimentary rock sources, Sediment. Geol., 113, 111124, 1997.

Francke, A., Wennrich, V., Sauerbrey, M., Juschus, O., Melles, M., and Brigham-Grette, J.: Multivariate statistic and time series analyses of grain-size data in quaternary sediments of Lake El'gygytgyn, NE Russia, Clim. Past, 9, 2459-2470, doi:10.5194/cp-9-2459-2013, 2013. 
Gallet, S., Jahn, B., Lanoe, B. V. V., Dia, A., and Rossello, E.: Loess geochemistry and its implications for particle origin and composition of the upper continental crust, Earth Planet. Sc. Lett., 56, 157-177, 1998

Goldberg, E. L., Phedorin, M. A., Grachev, M. A., Bobrov, V. A., Dolbnya, I. P., Khlystov, O. M., Levina, O. V., and Ziborova, G. A.: Geochemical signals of orbital forcing in the records of paleoclimates found in the sediments of Lake Baikal, Nucl. Instrum. Meth. A, 448, 384-393, 2000.

Hall, K., Thorn, C. E., Matsuoka, N., and Prick, A.: Weathering in cold regions: some thoughts and perspectives, Progr. Phys. Geogr., 26, 577-603, 2002.

Hammer, Ø., Harper, D. A. T., and Ryan, P. D.: PAST: Paleontological statistics software package for education and data analysis, Palaeontol. Electron., 4, 9 pp., 2001.

Harnois, L.: The CIW index: A new chemical index of weathering, Sediment. Geol., 55, 319-322, 1988.

Heiri, O., Lotter, A. F., and Lemcke, G.: Loss on ignition as a method for estimating organic and carbonate content in sediments: reproducibility and comparability of results, J. Paleolimnol., 25, 101-110, 2001.

Howard, W.: Awarm future in the past, Nature, 388, 418-419, 1997.

Jin, Z. D., Wang, S., Shen, J., Zhang, E., Ji, J., Li, F., and Lu, X.: Chemical weathering since the Little Ice Age recorded in lake sediments: a high-resolution proxy of past climate, Earth Surf. Proc. Land., 26, 775-782, 2001.

Jouzel, J., Masson-Delmotte, V., Cattani, O., Dreyfus, G., Falourd, S., Hoffmann, G., Minster, B., Nouet, J., Barnola, J. M., Chappellaz, J., Fisher, H., Gallet, J. C., Johnsen, S. J., Leuenberger, M., Loulergue, L., Luethi, D., Oerter, H., Parrenin, F., Raisbeck, G., Raynaud, D., Schilt, A., Schwander, J., Selmo, E., Souchez, R., Spahni, R., Stauffer, B., Steffensen, J. P., Stenni, B., Stocker, T., Tison, J. L., Werner, A., and Wolff, E. W.: Orbital and millennial Antarctic climate variability over the past 800,000 years, Science, 317, 793-796, 2007.

Just, J. and Kontny, A.: Thermally induced alterations of minerals during measurements of the temperature dependence of magnetic susceptibility: a case study from the hydrothermally altered Soultz-sous-Forêts granite, France, Int. J. Earth Sci., 101, 819839,2012

Kalugin, I., Daryin, A., Smolyaninova, L., Andreev, A., Diekmann, B., and Khlystov, O.: 800-yr-long records of annual air temperature and precipitation over southern Siberia inferred from Teletskoye Lake sediments, Quaternary Res., 67, 400-410, 2007.

Laskar, J., Robutel, P., Joutel, F., Gastineau, M., Correia, A. C. M., and Levrard, B.: A longterm numerical solution for the insolation quantities of the Earth, Astron. Astrophys., 428, 261-285, 2004.

Layer, P. W.: Argon-40/argon-39 age of the El'gygytgyn impact event, Chukotka, Russia, Meteorit. Planet. Sci., 35, 591-599, 2000 .

Le Maitre, R. W., Streckeisen, A., Zanettin, B., Le Bas, M. J., Bonin, B., Bateman, P., Bellieni, G., Dudek, A., Efremova, S., Keller, J., Lamere, J., Sabine, P. A., Schmid, R., Sorensen, H., and Wool, A. R.: Igneous rocks. A Classification and Glossary of Terms, in: Recommendation of the International Union of Geological Science Subcommission on the systematics of Igneous rocks, 2nd Edn., Cambridge University Press, 254 pp., 2002.
Lisiecki, L. E. and Raymo, M. E.: A Pliocene-Pleistocene stack of 57 globally distributed benthic $\delta^{18} \mathrm{O}$ records, Paleoceanography, 20, 1-17, 2005

Loizeau, J.-L., Span, D., Coppee, V., and Dominik, J.: Evolution of the trophic state of Lake Annecy (eastern France) since the last glaciation as indicated by iron, manganese and phosphorus speciation, J. Paleolimnol., 25, 205-214, 2001.

Lozhkin, A. V. and Anderson, P. M.: Vegetation responses to interglacial warming in the Arctic: examples from Lake El'gygytgyn, Far East Russian Arctic, Clim. Past, 9, 1211-1219, doi:10.5194/cp-9-1211-2013, 2013.

Lozhkin, A. V., Anderson, P. M., and Minyuk, P. S.: Interglacial, interstadial, and glacial intervals from a continuous climate record from sediments of El'gygytgyn Lake (Polar Chukotka) during the last 450 thousand years, VIII All-Russian conference on Quaternary Research: Fundamental problems of Quaternary research and main trends of future studied, SCS RAS Publisher, Rostovon-Don, 376-378, 2013.

Mackereth, F. J. H.: Some chemical observations on post-glacial lake sediments, Philos. T. Roy. Soc. B, 256, 165-213, 1966.

Maslov, A. V., Krupenin, M. T., and Gareev, E. Z.: Lithological, Lithochemical, and Geochemical Indicators of Paleoclimate: Evidence from Riphean of the Southern Urals, Lithol. Miner. Resour., 38, 427-446, 2003.

Matrosova, T.: Reconstruction of vegetation and climate in northern Chukotka during the last 20350 thousand years (according to palynological evidence from El'gygytgyn Lake), Vestnik SVNC DVO RAN, 1, 23-30, 2009

Melles, M., Brigham-Grette, J., Glushkova, O. Yu., Minyuk, P. S., Nowaczyk, N. R., and Hubberten, H.-W.: Sedimentary geochemistry of core PG1351 from Lake El'gygytgyn - a sensitive record of climate variability in the East Siberian Arctic during the past three glacial-interglacial cycles, J. Paleolimnol., 37, 89104, 2007.

Melles, M., Brigham-Grette, J., Minyuk, P., Koeberl, C., Andreev, A., Cook, T., Fedorov, G., Gebhardt, C., Haltia-Hovi, E., Kukkonen, M., Nowaczyk, N., Schwamborn, G., Wennrich, V., and the El'gygytgyn Scientific Party: The Lake El'gygytgyn Scientific Drilling Project - Conquering Arctic Challenges through Continental Drilling, Scient. Drill., 11, 29-40, 2011

Melles, M., Brigham-Grette, J., Minyuk, P. S., Nowaczyk, N. R., Wennrich, V., DeConto, R. M., Anderson, P. M., Andreev, A. A., Coletti, A., Cook, T. L., Haltia-Hovi, E., Kukkonen, M., Lozhkin, A. V., Rosén, P., Tarasov, P., Vogel, H., and Wagner, B.: 2.8 Million Years of Arctic Climate Change from Lake El'gygytgyn, NE Russia, Science, 337, 315-320, 2012.

Migdisov, A. A.: The Titanium-Aluminium Relationship in Sedimentary Rocks, Geokhimiya, 2, 149-163, 1960.

Minyuk, P. S., Brigham-Grette, J., Melles, M., Borkhodoev, V. Ya., and Glushkova, O. Yu.: Inorganic geochemistry of El'gygytgyn Lake sediments (northeastern Russia) as an indicator of paleoclimatic change for the last $250 \mathrm{kyr}$, J. Paleolimnol., 37, 123-133, 2007.

Minyuk, P. S., Borkhodoev, V. Ya., and Goryachev, N. A.: Geochemical Characteristics of Sediments from Lake El'gygytgyn, Chukotka Peninsula, as Indicators of Climatic Variations for the Past 350 ka, Dokl. Earth Sci., 436, 94-97, 2011. 
Minyuk, P. S., Subbotnikova, T. V., Brown, L. L., and Murdock, K. J.: High-temperature thermomagnetic properties of vivianite nodules, Lake El'gygytgyn, Northeast Russia, Clim. Past, 9, 433-446, doi:10.5194/cp-9-433-2013, 2013.

Nesbitt, H. W. and Young, G. M.: Early Proterozoic climates and plate motions inferred from major element chemistry of lutites, Nature, 299, 715-717, 1982.

Nesbitt, H. W. and Young, G. M.: Prediction of some weathering trends of plutonic and volcanic rocks based on thermodynamic and kinetic considerations, Geochim. Cosmochim. Acta, 48, 1523-1534, 1984.

Nolan, M.: Quantitative and qualitative constraints on hind-casting the formation of multiyear lake-ice covers at Lake El'gygytgyn, Clim. Past, 9, 1253-1269, doi:10.5194/cp-9-1253-2013, 2013.

Nolan, M. and Brigham-Grette, J.: Basic hydrology, limnology, and meteorology of modern Lake El'gygytgyn, Siberia, J. Paleolimnol., 37, 17-35, 2007.

Nowaczyk, N. R., Melles, M., and Minyuk, P.: A revised age model for core PG1351 from Lake El'gygytgyn, Chukotka, based on magnetic susceptibility variations tuned to northern hemisphere insolation variations, J. Paleolimnol., 37, 65-76, 2007.

Nowaczyk, N. R., Haltia, E. M., Ulbricht, D., Wennrich, V., Sauerbrey, M. A., Rosén, P., Vogel, H., Francke, A., MeyerJacob, C., Andreev, A. A., and Lozhkin, A. V.: Chronology of Lake El'gygytgyn sediments - a combined magnetostratigraphic, palaeoclimatic and orbital tuning study based on multiparameter analyses, Clim. Past, 9, 2413-2432, doi:10.5194/cp-92413-2013, 2013.

Ortega, B., Caballero, M., Lozano, S., Vilaclara, G., and Rodríguez, A.: Rock magnetic and geochemical proxies for iron mineral diagenesis in a tropical lake: Lago Verde, Los Tuxtlas, East-Central Mexico, Earth Planet. Sc. Lett., 250, 444-458, 2006.

Parker, A. G., Goudie, A. S., Stokes, S., White, K., Hodson, M. J., Manning, M., and Kennet, D.: A record of Holocene climate change from lake geochemical analyses in southeastern Arabia, Quaternary Res., 66, 465-476, 2006.

Pistolato, M., Quaia, T., Marinoni, L., Vitturi, L. M., Salvi, C., Salvi, G., Setti, M., and Brambati, A.: Grain Size, Mineralogy and Geochemistry in Late Quaternary Sediments from the Western Ross Sea outer Slope as Proxies for Climate Changes, in: Antarctica: Contributions to global earth sciences, edited by: Fütterer, D. K., Damaske, D., Kleinschmidt, G., Miller, H., and Tessensohn, F., Springer-Verlag, Berlin, Heidelberg, New York, 423-432, 2006.

Price, J. R. and Velbel, M. A.: Chemical weathering indices applied to weathering profiles developed on heterogeneous felsic metamorphic parent rocks, Chem. Geol., 202, 397-416, 2003.

Prokopenko, A. A., Hinnov, L. A., Williams, D. F., and Kuzmin, M. I.: Orbital forcing of continental climate during the Pleistocene: a complete astronomically tuned climatic record from Lake Baikal, SE Siberia, Quaternary Sci. Rev., 25, 3431-3457, 2006.

Prokopenko, A. A., Bezrukova, E. V., Khursevich, G. K., Solotchina, E. P., Kuzmin, M. I., and Tarasov, P. E.: Climate in continental interior Asia during the longest interglacial of the past 500000 years: the new MIS 11 records from Lake Baikal, SE Siberia, Clim. Past, 6, 31-48, doi:10.5194/cp-6-312010, 2010.
Reynolds, R. L., Rosenbaum, J. G., Rapp, J., Kerwin, M. W., Bradbury, J. P., Colman, S., and Adam, D.: Record of late Pleistocene glaciation and deglaciation in the southern Cascade Range, I. Petrological evidence from lacustrine sediment in Upper Klamath Lake, southern Oregon, J. Paleolimnol., 31, 217233, 2004.

Roman-Ross, G., Depetris, P. J., Arribere, M. A., Guevara, S. R., and Cuello, G. J.: Geochemical variability since the Late Pleistocene in Lake Mascardi sediments, northern Patagonia, Argentina, J. Soc. Am. Earth Sci., 15, 657-667, 2002.

Roy, P. D., Caballero, M., Lozano, R., Ortega, B., Lozano, S., Pi, T., Israde, I., and Morton, O.: Geochemical record of Late Quaternary paleoclimate from lacustrine sediments of paleo-lake San Felipe, western Sonora Desert, Mexico, J. Soc. Am. Earth Sci., 29, 586-596, 2010.

Sapota, T., Aldahan, A., and Al-Aasm, I. S.: Sedimentary facies and climate control on formation of vivianite and siderite microconcretions in sediments of Lake Baikal, Siberia, J. Paleolimnol., 36, 245-257, 2006.

Sauerbrey, M. A., Juschus, O., Gebhardt, A. C., Wennrich, V., Nowaczyk, N. R., and Melles, M.: Mass movement deposits in the 3.6 Ma sediment record of Lake El'gygytgyn, Far East Russian Arctic, Clim. Past, 9, 1949-1967, doi:10.5194/cp-9-19492013, 2013.

Schwamborn, G., Fedorov, G., Ostanin, N., Schirrmeister, L., Andreev, A., and the El'gygytgyn Scientific Party: Depositional dynamics in the El'gygytgyn Crater margin: implications for the 3.6 Ma old sediment archive, Clim. Past, 8, 1897-1911, doi:10.5194/cp-8-1897-2012, 2012.

Sharma, S., Joachimski, M., Sharma, M., Tobschall, H. J., Singh, I. B., Sharma, C., Chauhan, M. S., and Morgenroth, G.: Late glacial and Holocene environmental changes in Ganga plain, Northern India, Quaternary Sci. Rev., 23, 145-159, 2004.

Snyder, J. A., Cherepanova, M. V., and Bryan, A.: Dynamic diatom response to changing climate $0-1.2 \mathrm{Ma}$ at Lake El'gygytgyn, Far East Russian Arctic, Clim. Past, 9, 1309-1319, doi:10.5194/cp9-1309-2013, 2013.

Spahni, R., Chappellaz, J., Stocker, T. F., Loulergue, L., Hausammann, G., Kawamura, K., Flückiger, J., Schwander, J., Raynaud, D., Masson-Delmotte, V., and Jouzel, J.: Atmospheric Methane and Nitrous Oxide of the Late Pleistocene from Antarctic Ice Cores, Science, 310, 1317-1321, 2005.

Taboada, T., Cortizas, A. M., García, C., and García-Rodeja, E.: Particle-size fractionation of titanium and zirconium during weathering and pedogenesis of granitic rocks in NW Spain, Geoderma, 131, 218-236, 2006.

Tanaka, K., Akagawa, F., Yamamoto, K., Tani, Y., Kawabe, I., and Kawai T.: Rare earth element geochemistry of Lake Baikal sediment: its implication for geochemical response to climate change during the Last Glacial/Interglacial transition, Quaternary Sci. Rev., 26, 1362-1368, 2007.

Tarasov, P. E., Andreev, A. A., Anderson, P. M., Lozhkin, A. V., Leipe, C., Haltia, E., Nowaczyk, N. R., Wennrich, V., BrighamGrette, J., and Melles, M.: A pollen-based biome reconstruction over the last 3.562 million years in the Far East Russian Arctic new insights into climate-vegetation relationships at the regional scale, Clim. Past, 9, 2759-2775, doi:10.5194/cp-9-2759-2013, 2013. 
Taylor, S. R. and McLennan, S. M.: The continental crust: its composition and evolution, Blackwell, London, p. 31, 1985.

Tomirdiaro, C. V.: Permafrost and development of mountain areas and lowlands (Magadan region and Yakutia), Booking Press, Magadan, p. 174, 1972.

Tomirdiaro, C. V. and Chernen'ky, B. I.: Cryogenic-eolian deposits of east Arctic and Sub-Arctic, Nauka, Moscow, p. 196, 1987.

Treshnikov, A. F.: Atlas of the Arctic, Main Department of Geodesy and Cartography under the Council of Ministers of the USSR, Moscow, 1985.

Vegas, J., Ruiz-Zapata, B., Ortiz, J. E., Galan, L., Torres, T., García-Cortes, A., Gil-García, M. J., Perez-Gonzalez, A., and Gallardo-Millan, J. L.: Identification of arid phases during the last $50 \mathrm{cal} . \mathrm{kaBP}$ from the Fuentillejo maar-lacustrine record (Campo de Calatrava Volcanic Field, Spain), J. Quaternary Sci., 25, 1051-1062, 2010.

Vogel, H., Meyer-Jacob, C., Melles, M., Brigham-Grette, J., Andreev, A. A., Wennrich, V., Tarasov, P. E., and Rosén, P.: Detailed insight into Arctic climatic variability during MIS 11c at Lake El'gygytgyn, NE Russia, Clim. Past, 9, 1467-1479, doi:10.5194/cp-9-1467-2013, 2013.

Von Eynatten, H., Tolosana-Delgado, R., and Karius, V.: Sediment generation in modern glacial setting: Grain-size and source-rock control on sediment composition, Sediment. Geol., 280, 80-92, 2012.

Wallmann, K., Aloisi, G., Haeckel, M., Tishchenko, P., Pavlova, G., Greinert, J., Kutterolf, S., and Eisenhauer, A.: Silicate weathering in anoxic marine sediments, Geochim. Cosmochim. Acta, 72, 3067-3090, 2008.

Weltje, G. J. and von Eynatten, H.: Quantitative provenance analysis of sediments: review and outlook, Sediment. Geol., 171, 1-11, 2004.

Wennrich, V., Francke, A., Dehnert, A., Juschus, O., Leipe, T., Vogt, C., Brigham-Grette, J., Minyuk, P. S., Melles, M., and El'gygytgyn Science Party: Modern sedimentation patterns in Lake El'gygytgyn, NE Russia, derived from surface sediment and inlet streams samples, Clim. Past, 9, 135-148, doi:10.5194/cp-9-135-2013, 2013a.
Wennrich, V., Minyuk, P. S., Borkhodoev, V. Ya., Francke, A., Ritter, B., Nowaczyk, N., Sauerbrey, M. A., Brigham-Grette, J., and Melles, M.: Pliocene to Pleistocene climate and environmental history of Lake El'gygytgyn, Far East Russian Arctic, based on high-resolution inorganic geochemistry data, Clim. Past Discuss., 9, 5899-5940, doi:10.5194/cpd-9-5899-2013, 2013 b.

White, A. F. and Blum, A. E.: Effects of climate on chemical weathering rates in watersheds, Geochim. Cosmochim. Acta, 59, 1729-1747, 1995.

Whitlock, C., Dean, W., Rosenbaum, J., Stevens, L., Fritz, S., Bracht, B., and Power, M.: A 2650-year-long record of environmental change from northern Yellowstone National Park based on a comparison of multiple proxy data, Quatern. Int., 188, 126138, 2008.

Xiao, S., Liu, W., Li, A., Yang, S., and Lai, Z.: Pervasive autocorrelation of the chemical index of alteration in sedimentary profiles and its palaeoenvironmental implications, Sedimentology, 57, 670-676, 2010.

Yang, S., Ding, F., and Ding, Z.: Pleistocene chemical weathering history of Asian arid and semi-arid regions recorded in loess deposits of China and Tajikistan, Geochim. Cosmochim. Acta, 70, 1695-1709, 2006.

Young, G. M. and Nesbitt, H. W.: Processes controlling the distribution of $\mathrm{Ti}$ and $\mathrm{Al}$ in weathering profiles, siliciclastic sediments and sedimentary rocks, J. Sediment. Res., 68, 448-455, 1998.

Yudovich, Ya. E. and Ketris, M. P.: Geochemical indicators of lithogenesis, Geoprint, Syktyvkar, p. 742, 2011.

Zhong, W., Pen, Z., Xue, J., Ouyang, J., Tang, X., and Cao, J.: Geochemistry of sediments from Barkol Lake in the westerly influenced northeast Xinjiang: Implications for catchment weathering intensity during the Holocene, J. Asian Earth Sci., 50, 7-13, 2012 . 